\title{
1. Climate change, catastrophe risk, and government stimulation of the insurance market - a study of transitional China
}

Insurance is something we tend to think about only after a disaster. ${ }^{1}$

\section{INTRODUCTION}

Due to climate-related extremes, growing populations in high-risk areas, and aging infrastructure but low levels of public and private investment in risk reduction measures, the world is more vulnerable to catastrophe disasters, and the losses are increasing significantly. ${ }^{2}$ How to manage catastrophe risk efficiently and cover disaster losses fairly is still a universal dilemma.

"Famine happens every three years, epidemic happens every six years, and natural hazard happens every twelve years." ${ }^{3}$ This old saying is a perfect description of natural disasters in China. Due to China's unusual size and regional diversity, as well as its distinctive history and current political-economic configuration of "socialism with Chinese characteristics," 4 its approach to handling disaster challenges is in many

1 Adam F. Scales, Nation of Policyholders: Governmental and Market Failure in Flood Insurance, 26 Mississippi College Law Review 3, 3 (2006).

2 Erwann Michel-Kerjan, Have We Entered an Ever-Growing Cycle on Government Disaster Relief, Presentation to US Senate Committee on Small Business and Entrepreneurship (2013).

3 Y.-M. Wei, J.-L. Jin and Q. Wang, Impacts of Natural Disasters and Disasters Risk Management in China: The Case of China's Experience in Wenchuan Earthquake, in Economic and Welfare Impacts of Disasters in East Asia and Policy Responses 641 (Y. Sawada and S. Oum eds., 2012).

4 "Socialism with Chinese characteristics" is a grand but marvelously vague expression. It was first raised by reformist politician Deng Xiaoping in 1984, and it stretches the acceptable ideological framework to allow the country to pursue 
ways unique. ${ }^{5}$ The Chinese mechanism for managing catastrophe risks or challenges is known as the "Whole-Nation System" (Juguo tizhi), which generally refers to the government's effort to deploy and allocate the whole nation's resources to fulfill a specific difficult task within a limited time and thus promote the nation's interest. ${ }^{6}$ The Whole-Nation System is not only a mechanism for coping with catastrophe disaster risks, but also a much larger political ideology for dealing with all kinds of landmark challenges. Besides catastrophe disaster relief, the Lunar Exploration Program and the Olympic Gold Medals Strategy are also famous examples of the Whole-Nation System.

In the field of natural disasters, the Whole-Nation System is a kind of emergency-driven management system and focuses on disaster emergency relief. To be clear, it is neither private insurance nor social insurance, but rather a government subsidy program. While effective in delivering emergency relief in the short term, it is not sustainable in terms of compensation in the long term due to certain government failures, which this chapter will describe. Comparing the Whole-Nation System with possible alternatives is illuminating and may provide important insights for its reform.

Private insurance is traditionally regarded as a major mechanism to cover losses caused by disasters. Even though underwriting catastrophe insurance is susceptible to market failures because of both supply-side and demand-side barriers, ${ }^{7}$ it is still an attractive tool to comprehensively deal with catastrophe risk, especially compared with government intervention, due to its advantages of lower transaction costs, lower adverse selection, and greater efficiency as a result of competitive markets. ${ }^{8}$

In this chapter, I try to assess the Chinese government's responsibilities

policies that worked. See Ezra F.Vogel, Deng Xiaoping and the Transformation of China 465 (2011).

5 Elizabeth J. Perry, Growing Pains: Challenges for a Rising China, 143 Daedalus 5 (2014).

6 Peijun Shi and Xin Zhang, Chinese Mechanism against Catastrophe Riskthe Experience of Great Sichuan Earthquake, 28 Journal of Tsinghua University (Philosophy and Social Sciences) 96 (2013).

7 Qihao He, Climate Change and Financial Instruments to Cover Disasters: What Role for Insurance? in The Role of Law and Regulation in Sustaining Financial Markets 228 (Niels Philipsen et al. eds., 2015).

8 See Dwight Jaffe and Thomas Russell, Catastrophe Insurance, Capital Markets, and Uninsured Risks, 62 Journal of Risk and Insurance 225 (1997); Howard Kunreuther, The Case for Comprehensive Disaster Insurance, 11 Journal of Law and Economics 133 (1968); Howard Kunreuther, Mitigating Disaster Losses through Insurance, 12 Journal of Risk and Uncertainty 171 (1996); George L. Priest, The Government, the Market, and the Problem of Catastrophe Loss, 12 Journal of Risk and Uncertainty 219 (1996). 
under the Whole-Nation System, highlighting what is unique or unusual (for better or worse) in efforts to resolve the universal dilemma of catastrophe risks. Furthermore, I will discuss the Chinese government's responsibilities for embracing and developing catastrophe insurance (although cognizant of some market failures), and then propose a catastrophe insurance marketenhancing framework that marries the merits of both private market and public government to address the universal dilemma of natural disasters.

\section{NATURAL DISASTERS AND THEIR IMPACTS IN CHINA}

\section{A. Overview}

China routinely suffers some of the most severe natural catastrophes in the world. Floods, droughts, earthquakes, typhoons, and landslides/mudslides are the five most frequently occurring types. ${ }^{9}$ Floods hit the eastern part of China almost every year, and drought is perhaps the most severe natural disaster for agriculture, especially for North China. ${ }^{10}$ Historical records show that from $206 \mathrm{BC}$ to AD 1936 there were 1,037 floods and 1,035 droughts in China, averaging 0.967 floods or droughts per year. ${ }^{11}$ Typhoons affect the coastal areas in the southeast, much as hurricanes do in the United States. Earthquakes occur in the western and northern areas. For example, the Great Sichuan Earthquake struck the southwest and caused 69,277 deaths and around $\$ 100$ billion in losses in $2008 .{ }^{12}$ Since the founding of the People's Republic of China (PRC) in 1949, a "hazard cycle," which describes the phenomenon that a catastrophic disaster occurs every three years on average, has clearly existed based on data calculations. ${ }^{13}$ As early as the 1920s, Mallory described China bluntly as a "Land of Famine". ${ }^{14}$

9 Xian Xu and Jiawei Mo, The Impact of Disaster Relief on Economic Growth: Evidence from China, 38 The Geneva Papers on Risk and Insurance-Issues and Practice 495 (2013).

10 Walter H. Mallory, China: Land of Famine I-XVI (1926).

11 Y.T. Deng, History of Relief of Famines in China [Zhongguo Jiuhuang Shi] 38 (1937).

12 Hu Jintao, Address on the National Earthquake Relief Summary Commendation Conference [Zai Quanguo Kangzhen Jiuzai Zongjie Biaozhang Dahui Shangde Jianghua] (2008), available at http://wenku.baidu.com/view/90alb9b465ce0508763213de.html.

13 A.G. Hu, Natural Hazards and Economic Development in China [Zhongguo Ziran Zaihai yu Jingji Fazhan] 5-10 (1997).

14 Walter H. Mallory, China: Land of Famine (1926). 


\section{B. Climate Change Leads to More Catastrophes}

Climate change is occurring on a significant scale, and its effects are being felt on all continents and across the oceans. ${ }^{15}$ It is demonstrated that there is a clear link between climate change and many extreme weather-related catastrophes: "[A] changing climate leads to changes in the frequency, intensity, spatial extent, duration, and timing of extreme weather and climate events, and can result in unprecedented extreme weather and climate events". ${ }^{16}$

The impact of climate change for China has closely followed the global trend. In 2005, it was estimated that by 2020 , the national average surface temperature in China could increase by $1.7^{\circ} \mathrm{C}$; by $2030,2.2^{\circ} \mathrm{C}$; and by $2050,2.8^{\circ} \mathrm{C} .{ }^{17}$ The affected areas of climate warming extend from south to north.

The adverse consequences of climate change will be severe for China. More droughts will occur, the drought-prone area will continue to expand, and droughts will grow more intense. Except for the increased rainfall in the western part of the northwest, the northern and southern part of the northeast could become permanently dry. ${ }^{18}$ Meanwhile, floods, heavy rainfall, and landslides are likely to increase dramatically in the east of China. ${ }^{19}$ The increasing frequency and intensity of catastrophe disasters

15 IPCC, Climate Change 2014: Impacts, Adaptation, and Vulnerability (2014), available at http://www.ipcc.ch/report/ar5/wg2/.

16 IPCC, Summary for Policymakers in Managing the Risks of Extreme Events and Disasters to Advance Climate Change Adaptation 3 (C.B. Field, V. Barros, T.F. Stocker, D. Qin, D.J. Dokken, K.L. Ebi, M.D. Mastrandrea, K.J. Mach, G.-K. Plattner, S.K. Allen, M. Tignor and P.M. Midgley eds.), A Special Report of Working Groups I and II of the Intergovernmental Panel on Climate Change (Cambridge, UK: Cambridge University Press; New York, NY, USA) (2012).

17 D.H. Qin, Y.H. Ding, J.L. Su, J.W. Ren, S.W. Wang, R.S. Wu, X.Q. Yang, S.M. Wang, S.Y. Liu, G.R. Dong, Q. Lu, Z.G. Huang, B.L. Du and Y. Luo, Assessment of Climate and Environment Changes in China (I): Climate and Environment Changes in China and Their Projection, 2 (Suppl. 1) Advances in Climate Change Research 1 (2006).

18 D.H. Qin, Y.H. Ding, J.L. Su, J.W. Ren, S.W. Wang, R.S. Wu, X.Q. Yang, S.M. Wang, S.Y. Liu, G.R. Dong, Q. Lu, Z.G. Huang, B.L. Du, and Y. Luo, Assessment of Climate and Environment Changes in China (I): Climate and Environment Changes in China and Their Projection, 2 (Suppl. 1) Advances in Climate Change Research 1 (2006).

19 Based on the regression analysis of natural disaster occurrence and average global temperature from 1980 to 2010 , the frequency of epidemics, extreme temperature, floods, and storms was projected to increase by 506 times per year if the average global temperature increases by $1^{\circ} \mathrm{C}$. See Pan XB et al., Natural Disaster Occurrence and Average Global Temperature, 4 Disaster Advances 61 (2011). 
will no doubt aggravate the vulnerability of the socioeconomic development of China. ${ }^{20}$

\section{Losses Caused by Catastrophic Disasters}

China has become a booming economy-the second biggest in the world in 2009, with a per capita GDP of $\$ 6,100$ in 2012.. ${ }^{21}$ (All amounts of money are in US dollars unless designated with RMB.) China also has the largest population in the world, and most of it lives in South China and East China, both of which are vulnerable to floods, typhoons, landslides/ mudslides, and earthquakes. For example, the Pearl River Delta, a densely populated metropolitan area comprising Hong Kong, Guangzhou, and Shenzhen, is situated in one of the world's most disaster-prone regions. Floods and typhoons there put more people at risk than in any other metropolitan area in the world. ${ }^{22}$

As a consequence, the economic losses and the population affected by catastrophes are increasing significantly and causing much greater socioeconomic impacts in China. Relative to the period 1900-2012, China experienced the highest frequency of natural disasters from 2003 to 2012, accounting for 37.6 percent of total occurrences from 1900 to 2012. That decade also accounted for 55.5 percent of the economic losses and 52.4 percent of the affected population from 1900 to 2012 (Table 1.1). Data for almost the same time period (2004-2010) show that major natural disasters are frequent in China and losses caused by catastrophes there are significant (Table 1.2).

\section{THE WHOLE-NATION SYSTEM AND HOW IT WORKS IN CHINA}

Since 1949, the state has traditionally played the major role in covering risk and providing disaster relief in China. ${ }^{23}$ After launching the project

20 Sha Chen, Zhongkui Luo and Xubin Pan, Natural Disasters in China: 1900-2011, 69 Natural Hazards 1597 (2013).

21 Justin Yifu Lin, Demystifying the Chinese Economy, 46 The Australian Economic Review 259 (2013).

22 Swiss Re, Mind the Risk: Cities under Threat from Natural Disasters (2013), available at http://media.swissre.com/documents/Swiss_Re_Mind_the_risk.pdf.

23 Zhou Yanli (Vice President of China Insurance Regulatory Commission), speech at International Catastrophe Insurance Fund Management Symposium (2008), available at http://insurance.hexun.com/2008/jzfx/index.html. 
Table 1.1 Natural disasters of 2003-2012 in China, relative to the period 1900-2012 (percent)

\begin{tabular}{lcccc}
\hline Occurrences & Deaths & $\begin{array}{c}\text { Affected } \\
\text { population }\end{array}$ & $\begin{array}{c}\text { Direct } \\
\text { economic } \\
\text { loses }\end{array}$ \\
\hline Drought & 25.0 & 0.0 & 31.2 & 28.4 \\
Earthquake & 34.1 & 10.4 & 76.0 & 92.2 \\
Flooding & 53.0 & 0.1 & 35.6 & 38.8 \\
Landslide & 41.8 & 54.0 & 96.3 & 48.5 \\
Local storm & 39.0 & 18.6 & 19.8 & 68.7 \\
Tropical cyclone & 32.5 & 1.3 & 55.8 & 56.3 \\
Average & 37.6 & 14.1 & 52.4 & 55.5 \\
\hline
\end{tabular}

Notes:

Cited from Xian Xu \& Jiawei Mo, The Impact of Disaster Relief on Economic Growth: Evidence from China, 38 The Geneva Papers on Risk and Insurance-Issues and Practice 495-520 (2013).

Data include data up to 31 January 2012, 'Past Decade' roughly refers to the period from 2003 to 2012.

Source: EM-DAT: THE OFDA/CRED International Disaster Database, www.emdat. be-Université catholique de Louvain, Brussels (Belgium). Calculations and categorisation performed by the author.

of "reform and opening" (gaige kaifang) in 1978, the Chinese government gradually established disaster prevention, reduction, and relief mechanisms - collectively known as the "Whole-Nation System". ${ }^{24}$

In contrast with federal disaster policy in the United States, the WholeNation System is not the result of the failure of the private catastrophe insurance market but rather the child of China's history, economy, and socialist political system. Before considering what the content of the Whole-Nation System is and how it works, it is useful to examine the history of China's disaster policy.

\section{A. Historical Review of the Whole-Nation System: The Transformation of Disaster Risk Management since 1949}

Natural disaster management has been a highly sensitive issue for thousands of years in China. Building dams to prevent floods and protect

24 Ming Zou and Yi Yuan, China's Comprehensive Disaster Reduction, 1 International Journal of Disaster Risk Science 24 (2010). 
Table 1.2 Occurrences of major natural disasters in China, 2004-2010

\begin{tabular}{lrrrrrrrrr}
\hline Disasters & 2004 & 2005 & 2006 & 2007 & 2008 & 2009 & 2010 & Total $\begin{array}{c}\text { Loss } \\
\text { (bn SUS) }\end{array}$ \\
\hline Earthquake & 5 & 2 & 6 & 1 & 7 & 2 & 5 & 28 & 86.79 \\
Flood & 9 & 11 & 20 & 12 & 7 & 7 & 5 & 71 & 315.29 \\
Storm & 7 & 14 & 8 & 6 & 9 & 10 & 6 & 60 & 26.37 \\
Drought & 0 & 2 & 1 & 0 & 1 & 2 & 0 & 6 & 6.74 \\
Extreme & 1 & 1 & 0 & 0 & 2 & 0 & 0 & 4 & 21.10 \\
$\quad$ tempreture & & & & & & & & & \\
\hline
\end{tabular}

Note: Cited from Xian Xu and Jiawei Mo, The Impact of Disaster Relief on Economic Growth: Evidence from China, 38 The Geneva Papers on Risk and Insurance-Issues and Practice 495-520 (2013).

Source: EM-DAT: The OFDA/CRED international Disaster Database, www.emdat. be-Université catholique de Louvain, Brussels (Belgium). Calculation and Categotations performed by the author.

agricultural production was routinely regarded as a major function of the centralized government in ancient times. ${ }^{25}$ Disaster management was also stipulated by law and regulations. For example, "Records of Laws and Systems of Qing Dynasty" (Da Qing Hui Dian Shi Li, 1899) listed 12 articles identified as "Disaster Defense and Reduction Policies". ${ }^{26}$

Since the founding of the People's Republic of China (PRC) in 1949, disaster risk management policy has passed through two phases. The socialist government and a centrally planned economy were key features of the post-revolutionary order and had great influence on disaster policy in the first phase. The dawn of the Third Plenum of the Eleventh Party Congress in 1978 brought an entirely new set of socioeconomic reforms, including disaster risk management reform.

25 Tong Xing and Zhang Haibo, Disaster Management Analysis Framework Based on Chinese Problem [Jiyu Zhongguo Wenti De Zaihai Guanli Fenxi Kuangjia], 1 China Social Science 132 (2010); Karl August Wittfogel, Oriental Despotism: A Comparative Study of Total Power, I-XIX (1957).

26 The articles included but were not limited to the following: food supply, river control and levee building, eradication of locusts, information dissemination, and so on. See H. Chen, Disaster Defense and Reduction Policies in the Qing Dynasty [Qingdai fangzai Jianzai De Zhengce Yue Cuoshi], 3 Studies in Qing History [Qingshi Yanjiu] 41 (2004). 


\section{Phase I: A centrally planned state (1949-1978)}

The period from 1949 to 1978 saw the introduction of centrally planned disaster policies, accompanied by the shutting down of private insurance markets. During this period, people had no opportunity to buy insurance to cover their catastrophe exposures. The centrally planned economic system, not the mere existence of market failures, was responsible for the disappearance of private insurance. According to the requirements of socialist planned governance, there is no need - at least in theory ${ }^{27}$ - for business insurance because the government will bear all risks and cover individuals' exposures.

Meanwhile, the central government promulgated "Regulation on the Organization of National Disaster Relief Commission" (Zhongyang Jiuzai Weiyuanhui Zuzhi Jianze), which stipulated disaster policy as "self-rescue of victims, mutual support within social networks, and necessary assistance by government relief" ${ }^{28}$ Self-rescue of victims means citizens were expected to take care of themselves in times of disaster. Mutual support within social networks meant people should help each other within the local community. Although the government purported to cover individuals' exposures, the government lacked the capacity to compensate disaster victims. China was one of the poorest nations at that time. Even in 1978, the per capita income was only $\$ 154$, less than one-third of the average in Sub-Saharan African countries. ${ }^{29}$ Worse still, political leaders prioritized the development of large, heavy, advanced industries as they started building the nation, ${ }^{30}$ but paid less attention to natural disaster relief.

\section{Phase II: Reform and transition (since 1978)}

Along with the transformation from a centrally planned to a marketoriented economy (the so-called "reform and opening") starting in 1978, the disaster policy also underwent significant changes. The most significant feature of this period (since 1978) has been the dramatically increased government intervention and expansion of disaster relief.

27 According to the view of Karl Marx, "from each according to his ability, to each according to his need," with the full development of socialism, there will be enough to satisfy everyone's needs. See Karl Marx, Critique of the Gotha Program (1875), available at https://www.marxists.org/archive/marx/works/1875/ gotha/ch01.htm.

28 Gazette of the State Council of the People's Republic of China, Vol. 40 (1957).

29 Justin Yifu Lin, Demystifying the Chinese Economy, 46 The Australian Economic Review 259 (2013).

30 Justin Yifu Lin, Demystifying the Chinese Economy, 46 The Australian Economic Review 259 (2013). 
At present, relief and reconstruction after earthquakes, floods, typhoons, and other disasters is mostly financed by the government, along with social donations through the Red Cross and other charity NGOs. Unlike the actions in Phase I, the government has put the protection of people's lives and property higher on its agenda and has given a prominent position to natural disaster risk relief in its economic and social development plans. ${ }^{31}$

The comparison between the Tangshan Earthquake (1976) in Phase I and the Great Sichuan Earthquake (2008) in Phase II clearly shows the expansion of government relief and its changing priorities for disaster relief. Back in 1976, the Tangshan Earthquake, magnitude 7.5, killed 242,769 people. ${ }^{32}$ Central and local governments put RMB 4.3 billion into aid for disaster relief. In an effort to save face and assert its independence, the Chinese government refused offers of disaster aid and assistance from foreign countries and international organizations. ${ }^{33}$ In 2008, the Great Sichuan Earthquake, magnitude 8.0, caused 69,277 deaths. ${ }^{34}$ In contrast, central and local governments put RMB 128.7 billion into disaster relief, a 30 -fold increase. ${ }^{35}$ Furthermore, the attitude to foreign assistance had been completely reversed. Only two days after the earthquake, the Chinese government formally requested support from the international community and in total received $\$ 500$ million to help the families affected. ${ }^{36}$

The most convincing explanation for this change relates to China's miraculous success in economic growth since 1978, when China launched the project of "reform and opening". With GDP growing at an average

31 Office of National Commission for Disaster Reduction, P.R. China, China's Natural Disaster Risk Management, in Improving the Assessment of Disaster Risks to Strengthen Financial Resilience 121 (A Special Joint G20 Publication by the Government of Mexico and the World Bank, 2012).

32 USGS, Historical Earthquakes: Tangshan China, available at http://earthqu ake.usgs.gov/earthquakes/world/events/1976_07_27.php.

33 Wenying Tong, Comparative Study on Catastrophe Disaster Relief Mobilization Mode in China: Case study between Tangshan Earthquake and Sichun Earthquake, 5 Jianghai Academic Journal 94 (2010).

$34 \mathrm{Hu}$ Jintao, Address on the National Earthquake Relief Summary Commendation Conference [Zai Quanguo Kangzhen Jiuzai Zongjie Biaozhang Dahui Shangde Jianghua ] (2008), available at http://wenku.baidu.com/view/90a1b9 b465ce0508763213de.html.

35 Wenying Tong, Comparative Study on Catastrophe Disaster Relief Mobilization Mode in China: Case study between Tangshan Earthquake and Sichun Earthquake, 5 Jianghai Academic Journal 94 (2010) (even considering inflation (5.92 percent per year), there is still a five-fold increase).

36 Jiuchang Wei, Dingtao Zhao and Dora Marinova, Disaster Relief Drivers: China and the US in Comparative Perspective, 11 China: An International Journal 93 (2013). 
of 9.8 percent per year, and international trade growing by 16.6 percent annually over the past 33 years, China became an upper middle-income country, and more than 600 million people escaped poverty. ${ }^{37}$ Per capita GDP in China reached $\$ 6,100$ in $2012 .{ }^{38}$ With China's success in raising personal incomes, and individuals' relative risk aversion increasing with wealth, protection against the loss of existing income likely emerged as an increasingly significantly social objective. ${ }^{39}$ When the government began to obtain sufficient resources for disaster relief, disaster risk management became more important in the nation's policy agenda.

To date, China has established natural disaster risk management mechanisms featuring the role of government rather than that of the private insurance market. ${ }^{40}$ These mechanisms are collectively named the Whole-Nation System (Juguo tizhi). It is more like a government subsidized disaster relief program than social insurance. This could be defined through the discussion of the content of the Whole-Nation System.

\section{B. The Content of the Whole-Nation System}

\section{Origin}

The phrase "Whole-Nation System" is borrowed from China's Sovietstyle sports system. ${ }^{41}$ The Whole-Nation System was formed and promoted along with Chinese participation in the Olympic Games. It has taken China from no gold medals to the top of the tally - in the 2008 Beijing Olympic Games, China won 51 gold medals while the United States won 36 and Russia won 23-quenching the thirst of many Chinese for national pride. ${ }^{42}$ Olympic competition is one example of the

37 Barry Naughton, China's Economy: Complacency, Crisis \& the Challenge of Reform, 143 Daedalus 14 (2014).

38 Justin Yifu Lin, Demystifying the Chinese Economy, 46 The Australian Economic Review 259 (2013).

39 See Kenneth Arrow, Lecture 2: The Theory of Risk Aversion in Aspects of the Theory of Risk-Bearing 28 (1965).

40 Office of National Commission for Disaster Reduction, P.R. China, China's Natural Disaster Risk Management, in Improving the Assessment of Disaster Risks to Strengthen Financial Resilience 121 (A Special Joint G20 Publication by the Government of Mexico and the World Bank, 2012).

41 Under this system, the government seeks talented young children from across the country, and the nation's sporting resources are concentrated on those who aim to become world champions. See Liang Xiao-long, The Wholenation System: The Successful Road of the Chinese Athletic Sports, 26 Journal of Guangzhou Physical Education Institute 1 (2006).

42 Qingju Wang, From "the Whole Nation System" to "Chinese Model": Theoretical Demand Space of Chinese Sports System a Summary of the Forum 
Whole-Nation System working effectively in achieving a challenging objective in a short time.

The 1998 Yangtze River flood and the 2003 Severe Acute Respiratory Syndrome (SARS) epidemic were regarded as watershed events for the development of the Whole-Nation System in the area of disaster response. In 2007, the "Emergency Response Law" was promulgated. This law comprehensively stipulates emergency response plans, institutions, mechanisms, and legal systems, and emphasizes the dominant role of government in emergency response to natural disasters. ${ }^{43}$

\section{Operating agencies}

The Whole-Nation System operates under the unified leadership of the State Council (the Central People's Government). The central government is responsible for the coordination and organization of catastrophic disaster risk management. ${ }^{44}$ At the national level, the system is headed by the National Committee for Disaster Reduction (NCDR), which consists of 33 disaster-related member agencies (Figure 1.1). A vice premier of the State Council serves as the director of the NCDR, and the Minister of Civil Affairs acts as its secretariat. A board of experts serves as consultants for the NCDR. For specific disasters, the corresponding ministries or bureaus are responsible for governance and technical affairs. ${ }^{45}$ For example, the China Earthquake Administration takes charge of governance in the case of earthquakes, and the Ministry of Water Resources takes charge of governance in the case of floods and droughts. These coordinating bodies not only provide decision-making services for the NCDR on disaster response and relief but also implement its decisions. ${ }^{46}$ At the local level,

"Sports System Transition and Chinese Sports in the Future", 34 Journal of Sports and Science 1 (2013).

43 Yongqing Wang, Legislative Background and Overall Thinking on Emergency Response Law (December 10, 2007), available at http://www.gdemo.gov.cn/yjpx/ ztjz/200712/t20071210_37179.htm.

44 Office of National Commission for Disaster Reduction, P.R. China, China's Natural Disaster Risk Management in Improving the Assessment of Disaster Risks to Strengthen Financial Resilience 121 (A Special Joint G20 Publication by the Government of Mexico and the World Bank, 2012).

45 Y.-M. Wei, J.-L. Jin and Q. Wang, Impacts of Natural Disasters and Disasters Risk Management in China: The Case of China's Experience in Wenchuan Earthquake in Economic and Welfare Impacts of Disasters in East Asia and Policy Responses 641 (Y. Sawada and S. Oum eds., 2012).

46 Jiang Lingling et al., People's Republic of China: Providing Emergency Response to Sichuan Earthquake, Technical Assistance Consultant's Report to Ministry of Civil Affairs, P.R. China and Asian Development Bank (2008). 
corresponding organizations in accordance with the national level are also established.

National Committee for
Disaster Reduction-NCDR

Source: Jiang Lingling et al., People's Republic of China: Providing Emergency Response to Sichuan Earthquake, Technical Assistance Consultant's Report to Ministry of Civil Affairs, P.R. China and Asian Development Bank (2008).

\section{Figure 1.1 Disaster management organization structure}

\section{Systematic arrangements}

For a transition economy such as China, its legitimacy depends not only on its economic performance but also on its response and accountability to the people during disasters ${ }^{47}$ During the transition process, the Chinese

47 Y.A. Lazarev, A.S. Sobolev, I.V. Soboleva and B. Sokolov, Trial by Fire: A Natural Disaster's Impact on Support for the Authorities in Rural Russia, 66 World Politics 641, 642 (2014) ("The impact of natural disasters on support for 
government has come to prioritize disaster relief in its agenda. Since the early 1980s, China has promulgated more than 30 laws and regulations concerning disaster prevention, reduction, and relief. ${ }^{48}$ These laws and regulations cover different aspects of disaster risk management. ${ }^{49}$ Besides laws and regulations, the Chinese government has also announced several national strategic plans relating to disaster risk management. As a recent example, in 2007, the Chinese government issued the National Plans for Comprehensive Disaster Reduction in the Eleventh Five-Year-Plan

authorities is conditional on governmental performance during and after the shock").

48 These laws and regulations include but are not limited to: Emergency Response Law of the People's Republic of China, Law of the People's Republic of China on Water and Soil Conservation, Law of the People's Republic of China on Protection against and Mitigation of Earthquake Disasters, Water Law of the People's Republic of China, Flood Control Law of the People's Republic of China, Law of the People's Republic of China on Desertification Prevention and Transformation, Meteorology Law of the People's Republic of China, Forestry Law of the People's Republic of China, Grassland Law of the People's Republic of China, Law of the People's Republic of China on the Prevention and Control of Water Pollution, Law of the People's Republic of China on the Prevention and Control of Pollution from Environmental Noise, Law of the People's Republic of China on the Prevention and Control of Environmental Pollution from Solid Waste, Marine Environment Protection Law of the People's Republic of China, Fire Control Law of the People's Republic of China, Drought Control Regulations of the People's Republic of China, Hydrology Regulations of the People's Republic of China, Flood Control Regulations of the People's Republic of China, Forest Fire Control Regulations of the People's Republic of China, Grassland Fire Control Regulations of the People's Republic of China, Regulations on Handling Major Animal Epidemic Emergencies, Regulations on the Prevention and Control of Forest Plant Diseases and Insect Pests, Regulations on the Prevention and Control of Geological Disasters, Regulations on the Handling of Destructive Earthquake Emergencies, Regulations on the Administration of Security of Reservoirs and Dams, and Regulations on the Administration of Weather Modification. See Information Office of the State Council of the People's Republic of China, White Paper: China's Actions for Disaster Prevention and Reduction (2009), available at http://mzzt.mca.gov.cn/ article/fzjzgjhx/bps/200905/20090500030686.shtml.

49 Ming Zou and Yi Yuan, China's Comprehensive Disaster Reduction, 1 International Journal of Disaster Risk Science 24 (2010). For example, the Flood Control Law was promulgated in 1997 and revised in 2009, enacted to prevent and control flood, to take precautions against and alleviate calamities by flood and waterlogging, and to maintain the safety of people's lives and property. The Law of the People's Republic of China on Protecting against and Mitigating Earthquake Disasters came into force as of March 1, 1998, and was revised in 2009, intended to protect against and mitigate earthquake disasters and ensure the safety of people's lives and property. 
Period. ${ }^{50}$ Although it is difficult to evaluate how well these laws, regulations, and plans have been implemented, at least they reflect the government's concern for this issue. They stand for the government's willingness and efforts to prioritize disaster risk management on its agenda.

Under the Whole-Nation System, the government occupies the dominant position. In practice, government intervention can be classified into pre-disaster and post-disaster arrangements.

- Pre-disaster arrangements

These include conducting natural disaster risk investigation and zoning, establishing a natural disaster monitoring system and an early warning system, pushing forward natural disaster prevention projects, establishing National Comprehensive Disaster Reduction Demonstration Communities, drawing people's attention to disaster prevention through designating May 12 as National Disaster Prevention and Reduction Day. ${ }^{51}$

- Post-disaster arrangements

These include mobilizing national resources to deal with natural disasters, coordinating government and NGOs to implement disaster relief, organizing counterpart aid (duikou zhiyuan) to help disasteraffected areas, implementing reconstruction plans, and so on. ${ }^{52}$

Government fiscal support serves as the major capital source for disaster relief and post-disaster reconstruction. ${ }^{53}$ Government disaster relief can be categorized into three layers under the Whole-Nation System.

- Emergency response

This includes rescuing victims; providing medical treatment to injured people; providing food and shelter for victims; engaging in

50 Ming Zou and Yi Yuan, China's Comprehensive Disaster Reduction, 1 International Journal of Disaster Risk Science 24 (2010).

51 Office of National Commission for Disaster Reduction, P.R. China, China's Natural Disaster Risk Management, in Improving the Assessment of Disaster Risks to Strengthen Financial Resilience 121 (A Special Joint G20 Publication by the Government of Mexico and the World Bank, 2012).

52 K. Dalen, H. Flatø, L. Jing and Z. Huafeng, Recovering from the Wenchuan Earthquake. Living Conditions and Development in Disaster Areas 2008-2011, 39 (Oslo: FAFO, 2012).

53 Office of National Commission for Disaster Reduction, P.R. China, China's Natural Disaster Risk Management, in Improving the Assessment of Disaster Risks to Strengthen Financial Resilience 121 (A Special Joint G20 Publication by the Government of Mexico and the World Bank, 2012). 
water purification, sanitation, quarantine, and epidemic prevention; and restoring transportation and other infrastructure for public interest.

- Direct payment to victims

This includes a three-month temporary living subsidy to disasteraffected people, compensation to victim's families, compensation to the injured, orphans, the elderly, and the handicapped, and subsidies to help farm workers reconstruct their houses.

- Counterpart aid and reconstruction support

These include rebuilding houses for victims, making long-term grants and loans to restore commercial structures and businesses, and aiding the agricultural sector.

In short, unified leadership by the government is the foremost principle of the Whole-Nation System. ${ }^{54}$ It is a disaster-management system in which the government mobilizes, deploys, and allocates the nation's resources to cope with catastrophes, compensate victims, and conduct reconstruction, thus promoting the welfare of victims and the nation's interests. These interests extend beyond coping with a given disaster, including also promoting the government's image and fostering good relations between the various levels of government and the people. ${ }^{55}$ In other words, it is not insurance; instead, it consists of fiscal cash outlays.

\section{How the Whole-Nation System Works in Practice-a Case Study of the 2008 Great Sichuan Earthquake}

The 2008 Great Sichuan Earthquake showed how the Whole-Nation System worked. In 2008, an earthquake, magnitude 8.0, struck the Sichuan Province and caused 69,277 deaths. ${ }^{56}$ The losses exceeded $\$ 100$ billion. ${ }^{57}$ The Whole-Nation System played an essential role in coping with this catastrophic earthquake. This section provides a case study

\footnotetext{
54 He Wang, Research on Catastrophe Risk Insurance Mechanisms 65(2013).

55 He Wang, Research on Catastrophe Risk Insurance Mechanisms 65(2013).

56 Hu Jintao, Address on the National Earthquake Relief Summary Commendation Conference [Zai Quanguo Kangzhen Jiuzai Zongjie Biaozhang Dahui Shangde Jianghua] (2008), available at http://wenku.baidu.com/view/90a1b9b465ce050876 3213de.html.

$57 \mathrm{Hu}$ Jintao, Address on the National Earthquake Relief Summary Commendation Conference [Zai Quanguo Kangzhen Jiuzai Zongjie Biaozhang Dahui Shangde Jianghua] (2008), available at http://wenku.baidu.com/view/90alb9b465 ce0508763213de.html.
} 


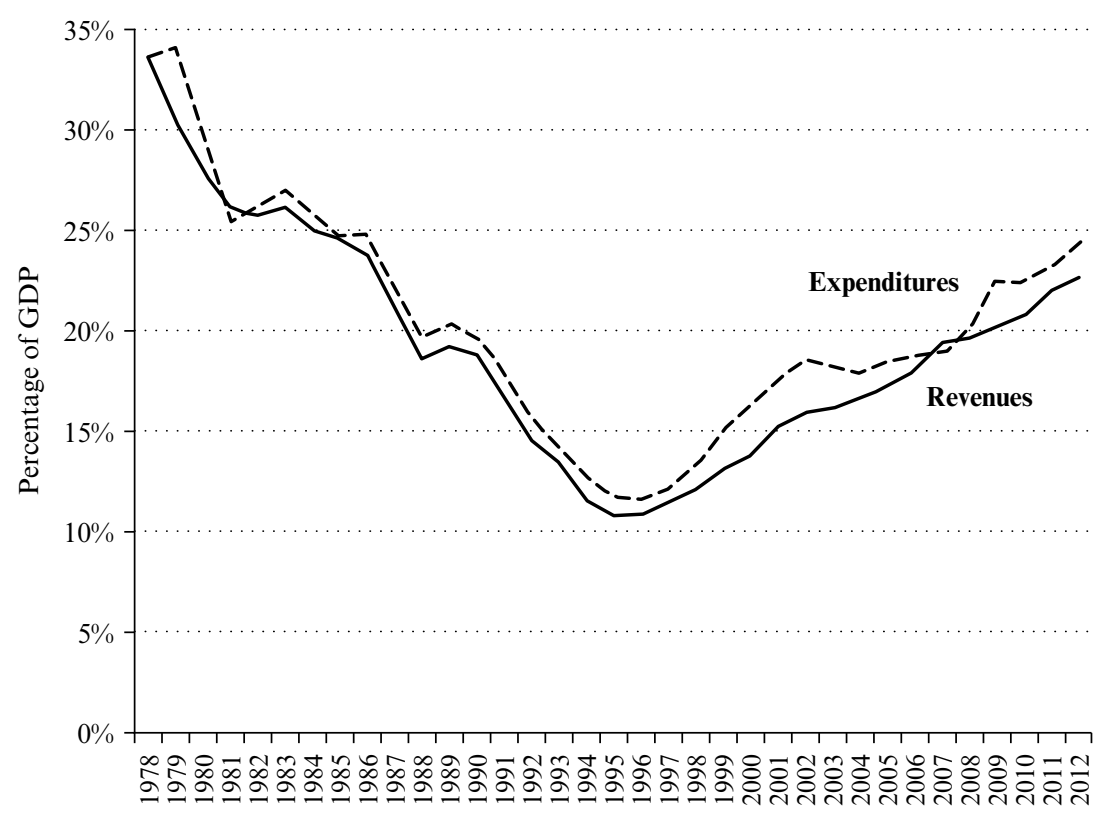

Source: Barry Naughton, China's Economy: Complacency, Crisis \& the Challenge of Reform, 143 Daedalus 14 (2014).

Figure 1.2 China's budget share in GDP, 1978-2012

of the Whole-Nation System in operation following the Great Sichuan Earthquake.

\section{Undertaking disaster relief and compensating victims}

Since the transition from a planned economy to a market economy in 1979, China has grown to be the second largest economy in the world, and its government has gained the unique ability to undertake disaster relief. After 1995, social resources available to the government, particularly for the central government, grew enormously due to both overall economic development and fiscal reform. Tax revenues as a share of GDP illustrate this dramatic change (Figure 1.2). Considering the rapid growth of the GDP itself, real budgetary revenues were almost 20 times in 2012 what they had been in $1995 .{ }^{58}$ In 2012, Chinese government revenues at $\$ 1.86$

58 Budget revenues increased from 10.8 percent of GDP in 1995 to 22.6 percent of GDP in 2012, and the annual GDP growth averaged 9.8 percent over the period. 
trillion were about equal to the US federal government on-budget revenues, which are estimated by the Congressional Budget Office at \$1.97 trillion (excluding Social Security).

Thanks to its economic power, the Chinese government has the ability to play a facilitating role in disaster relief. In the immediate aftermath of the Great Sichuan Earthquake, which occurred on May 12, 2008, the central government appropriated $\$ 83$ million to victims that evening; within one week, the central government supplied more than $\$ 400$ million in earthquake relief. ${ }^{59}$ Within four months, the government had created an emergency disaster relief fund in the amount of about $\$ 11$ billion, ${ }^{60}$ while the losses from the earthquake were around $\$ 100$ billion. On September 23, 2008, the State Council announced a "Notice on the State Council Overall Planning for Post-Great Sichuan Earthquake Restoration and Reconstruction" (hereinafter "the Plan"). According to the Plan, more than \$157 billion was to be allocated for restoration work in the 51 disaster-affected counties in the provinces of Sichuan, Gansu, and Shaanxi. ${ }^{61}$

Direct payment to victims from government disaster relief funds is an important feature of the Whole-Nation System. Disaster relief funds were spent on victims mainly in the following ways. First, the funds were used to supply a three-month temporary living subsidy to earthquake-affected people. From May 20, this subsidy was about RMB 10 plus $0.5 \mathrm{~kg}$ of grain product every day to those affected people who had no residence and no income.$^{62}$ Second, the fund supplied compensation to victims' families. The number of fatalities was more than 70,000 , and the government provided each victim's family with RMB $5,000 .{ }^{63}$ Third, it compensated the injured, orphans, the elderly living

See Barry Naughton, China's Economy: Complacency, Crisis \& the Challenge of Reform, 143 Daedalus 14 (2014).

59 Xinhua News Agency, Central Government Appropriated $\$ 400$ Million to Earthquake Relief (May 15, 2008), available at http://news.xinhuanet.com/newscenter/2008-05/15/content_8180172.htm.

60 Peijun Shi and Xin Zhang, Chinese Mechanism against Catastrophe Riskthe Experience of Great Sichuan Earthquake, 28 Journal of Tsinghua University (Philosophy and Social Sciences) 96 (2013).

61 The State Council (23 September, 2008), available at http://www.gov.cn/ zwgk/2008-09/23/content_1103686.htm.

62 Jiang Lingling et al., People's Republic of China: Providing Emergency Response to Sichuan Earthquake, Technical Assistance Consultant's Report to Ministry of Civil Affairs, P.R. China and Asian Development Bank (2008).

63 Jiang Lingling et al., People's Republic of China: Providing Emergency Response to Sichuan Earthquake, Technical Assistance Consultant's Report to Ministry of Civil Affairs, P.R. China and Asian Development Bank (2008). 
alone, and the handicapped affected by the earthquake (RMB 600 per month). The government launched a special mechanism to mobilize 375 hospitals from 20 provinces to treat more than 10,000 seriously injured victims, providing RMB 28,000 in medical subsidies for each injured person. For those with minor wounds, around 374,000 people, their medical treatment was free of charge.$^{64}$ Fourth, the government supplied subsidies to help farmers reconstruct their houses. In early June, the State Council decided that it would pay an average of RMB 10,000 per household to farmers whose houses collapsed or were severely damaged or who became homeless in the earthquake-affected region including Sichuan, Gansu, and Shaanxi provinces, for the purpose of reconstructing their houses. ${ }^{65}$

Three years after the earthquake, when the recovery and reconstruction period outlined in the Plan were over, the surveys of victims showed that most households' living conditions had indeed recovered to preearthquake levels or better. ${ }^{66}$ For example, housing and employment goals, as the first two objectives of the Plan, had been largely fulfilled. Almost everyone in the earthquake-affected area lived in a permanent house, with only 0.6 percent of households still living in temporary houses or tents. ${ }^{67}$ The employment rate was indeed relatively high, with the unemployment rate at only 2 percent; and household income also increased considerably. ${ }^{68}$

\section{Mobilizing military power for emergency disaster relief}

The Chinese People's Liberation Army (PLA) has a long history of involvement in disaster relief and constitutes an integral part of the Whole-Nation System. Due to the central government's mobilization and

64 Jiang Lingling et al., People's Republic of China: Providing Emergency Response to Sichuan Earthquake, Technical Assistance Consultant's Report to Ministry of Civil Affairs, P.R. China and Asian Development Bank (2008).

65 Jiang Lingling et al., People's Republic of China: Providing Emergency Response to Sichuan Earthquake, Technical Assistance Consultant's Report to Ministry of Civil Affairs, P.R. China and Asian Development Bank (2008).

66 K. Dalen, H. Flatø, L. Jing and Z. Huafeng, Recovering from the Wenchuan Earthquake. Living Conditions and Development in Disaster Areas 2008-2011, 39 (Oslo: FAFO, 2012).

67 K. Dalen, H. Flatø, L. Jing, and Z. Huafeng, Recovering from the Wenchuan Earthquake. Living Conditions and Development in Disaster Areas 2008-2011, 39 (Oslo: FAFO, 2012).

68 K. Dalen, H. Flatø, L. Jing, and Z. Huafeng, Recovering from the Wenchuan Earthquake. Living Conditions and Development in Disaster Areas 2008-2011, 39 (Oslo: FAFO, 2012). 
the PLA's command-and-control structure, the PLA made significant contributions to the operation of the Whole-Nation System, especially in the emergency response to disasters.

In recent years, the mounting frequency of and losses from natural catastrophes in China has placed increasing demands on the military to be deployed to domestic disaster relief under its powers to conduct "military operations other than war" ${ }^{69}$ China, as a developing country, lacks sufficient civilian emergency management capacity compared with Western countries, and thus the military has been a powerful, energetic, and integral part of the Whole-Nation System. In 2005, the State Council and the Central Military Commission jointly promulgated the "Regulation on the Army's Participation in Disaster Rescue", which designated the PLA as the "shock force" in national responses to catastrophic disasters. ${ }^{70}$

The PLA contributes significantly to the efficiency of the Whole-Nation System in disaster emergency response and relief. First, the military responded with unprecedented speed to the earthquake and made the best use of the golden hours of disaster rescue to save as many as lives as possible. ${ }^{71}$ Only 13 minutes after the earthquake, the PLA activated the military plan for handling emergency incidents. Within 10 hours, 12,000 PLA and People's Armed Police (PAP) soldiers arrived and undertook earthquake rescue; and on the next day, another 11,420 troops arrived by air transportation alone. ${ }^{72}$ Second, the civilian government made use of the military's vertical command-and-control structure to improve relief efficiency under conditions of catastrophic losses. Within the PLA, a three-tiered command system was quickly set up to oversee the military's relief operation, and these ad hoc institutions were also subject to the leadership of the civilian government at the corresponding level. ${ }^{73}$ Third, the military undertook wide-ranging relief activities, counting on its huge numbers of troops. The PLA is the largest army in the world, and it can

69 William Banks, Who's in Charge: The Role of the Military in Disaster Response, 26 Mississippi College Law Review 75 (2007).

70 Ministry of Defense of PRC, (2005) available at http://www.mod.gov.cn/ policy/2011-09/26/content_4300880.htm.

71 Jian Zhang, The Military and Disaster Relief in China: Trends, Drivers and Implications, in Disaster Relief in the Asia Pacific: Agency and Resilience 79 (Minako Sakai et al. eds., 2014).

72 W. Chen, Zhijing! Xinshiqi Zuikeai de Ren [Pay Tribute to the Most Beloved People in the New Period], 8 Dangshi Yanjiu [Journal of Party History] 1 (2008).

73 Jian Zhang, The Military and Disaster Relief in China: Trends, Drivers and Implications, in Disaster Relief in the Asia Pacific: Agency and Resilience 79-80 (Minako Sakai et al. eds., 2014). 
Table 1.3 Numbers of soldiers that have participated in major disaster relief and Olympics security since 1998

\begin{tabular}{llcc}
\hline Year & Event & $\begin{array}{c}\text { PLA and PAP } \\
\text { TROOPS }\end{array}$ & $\begin{array}{c}\text { Reserve } \\
\text { and Militia }\end{array}$ \\
\hline 1998 & $\begin{array}{l}\text { Major flooding of the Yangtze, } \\
\text { Songhua, and Nen Rivers }\end{array}$ & 300,000 & $5,000,000$ \\
2002 & $\begin{array}{l}\text { Flooding in Shanxi, Fujjian, and 19 } \\
\text { other provinces }\end{array}$ & 20,000 & 170,000 \\
2003 & Flooding of the Huai River in Jiangxi, & 48,000 & 410,000 \\
& Hunan, and Shanxi provinces & & \\
2008 & Snow and ice storms in 21 provinces & 224,000 & $1,036,000$ \\
2008 & Earthquake in Wenquan, Sichuan & 146,000 & 75,000 \\
2008 & Security for the Olympics & 131,000 & na \\
2010 & Earthquake in Yushu, Sichuan & 16,000 & na \\
2010 & Mudslides in Zhouqu, Gansu & 7,600 & na \\
\hline
\end{tabular}

Source: Taylor Fravel, Economic Growth, Regime Insecurity, and Military Strategy: Explaining the Rise of Noncombat Operations in China, 7 Asian Security 177-200 (2011).

quickly mobilize a large number of soldiers to handle disasters, as it has throughout the PRC's history (Table 1.3). As many as 146,000 troops were deployed, and they evacuated around 1.4 million people, provided medical treatment to 1.36 million injured people, and rescued 3,338 people. ${ }^{74}$ Furthermore, they also restored road transportation; provided food and shelter for victims; and engaged in water purification, sanitation, quarantine, and epidemic prevention, and the like. ${ }^{75}$ Even though the majority of PLA troops withdrew within three months of the earthquake, some engineering units stayed for another three months to assist with post-earthquake reconstruction. ${ }^{76}$

74 Jian Zhang, The Military and Disaster Relief in China: Trends, Drivers and Implications, in Disaster Relief in the Asia Pacific: Agency and Resilience 80 (Minako Sakai et al. eds., 2014).

75 Jian Zhang, The Military and Disaster Relief in China: Trends, Drivers and Implications, in Disaster Relief in the Asia Pacific: Agency and Resilience 80 (Minako Sakai et al. eds., 2014).

76 Jian Zhang, The Military and Disaster Relief in China: Trends, Drivers and Implications, in Disaster Relief in the Asia Pacific: Agency and Resilience 80 (Minako Sakai et al. eds., 2014). 


\section{Counterpart aid (Duikou Zhiyuan): National "pooling" of catastrophe risk among provincial and local governments}

Pooling is a fundamental mechanism in both public risk management and private insurance. Its basic principle lies in combining and spreading a sufficient number of exposures across as large a group as possible. ${ }^{77}$ Counterpart aid (duikou zhiyuan) is a mechanism that, under the central government's organization, requires some provinces that have stronger economic power to assist and support the reconstruction of disasteraffected areas. ${ }^{78}$ This aid is generally conducted on a one-to-one basis, under the principle of "one province helps one significantly affected county". ${ }^{79}$ The match criterion set up by the central government is that the richest donor provinces will contribute to the hardest-hit victim areas, while the less wealthy provinces will be asked to do less, and the least wealthy provinces will not be assigned any victim areas. According to the Plan, 18 heavily affected counties in Sichuan Province were supported by 18 other provinces or municipalities. For example, Guangdong Province - the richest province measured by GDP - was responsible for the reconstruction of Wenchuan County, which was the epicenter of the earthquake and suffered the most severe losses. Shandong Province-the second richest province in 2008 - was responsible for and supported the reconstruction of BeiChuan County, which was the neighbor of Wenchuan County and was also heavily hit by the earthquake. Meanwhile, Gansu Province, Guizhou Province, and other less wealthy provinces had no responsibility for counterpart aid.

Under the framework of counterpart aid, supporting provinces are required to donate 1 percent of their fiscal revenue from the preceding year to supported counties for reconstruction in the next three

77 David A. Moss, When All Else Fails: Government as the Ultimate Risk Manager 292-296 (2004); E.J. Vaughan and T.M. Vaughan, Fundamentals of Risk and Insurance 34-44 (2007).

78 Y. Lan, A Study on the Counterpart Aid: A Cooperation Pattern between Local Governments with Chinese Characteristics [Duikou Zhiyuan: Zhongguo Tese De Difang Zhengfu Jian Hezuo Moshi Yanjiu], Thesis of the College of Political and Law of Northwest Normal University [XiBei Shifan Daxue Shuoshi Xuewei Lunwen] (2011); L. Zhao and Y.J. Jiang, Analysis of Local Government Coordinated Assistance Modes [Difang Zhengfu Duikou Zhiyuan Moshi Fenxi], 2 Journal of ChengDu University (Social Science Edition) [ChengDu Daxue Xuebao (Sheke Ban)] 4, 25 (2009).

79 Y.-M. Wei, J.-L. Jin and Q. Wang, Impacts of Natural Disasters and Disasters Risk Management in China: The Case of China's Experience in Wenchuan Earthquake in Economic and Welfare Impacts of Disasters in East Asia and Policy Responses 641 (Y. Sawada and S. Oum eds., 2012). 
Table 1.4 Performance of some supporting provinces in counterpart aid in response to the 2008 Great Sichuan Earthquake (RMB billions)

\begin{tabular}{lcclc}
\hline $\begin{array}{l}\text { Supporting } \\
\text { provinces or } \\
\text { municipalities }\end{array}$ & $\begin{array}{c}\text { Fiscal revenue } \\
(2007)\end{array}$ & $\begin{array}{c}\text { Required } \\
\text { counterpart } \\
\text { aid (1\%) }\end{array}$ & $\begin{array}{l}\text { Supported } \\
\text { counties }\end{array}$ & $\begin{array}{c}\text { Actual } \\
\text { counterpart aid } \\
(2008)\end{array}$ \\
\hline Guangdong & 278.526 & 2.785 & Wenchuan & 4.162 \\
Jiangsu & 223.666 & 2.236 & Mianzhu & 4.363 \\
Zhejiang & 164.949 & 1.649 & Qingchuan & 3.499 \\
Shanghai & 207.448 & 2.074 & Dujiangyan & 6.198 \\
Beijing & 164.964 & 1.649 & Shifang & 5.306 \\
Liaoning & 108.199 & 1.081 & Anxian & 2.6 \\
Fujian & 70.03 & 0.703 & Pengzhou & 3.318 \\
Anhui & 54.347 & 0.534 & Songpan & 1.889 \\
\hline
\end{tabular}

Source: Zhongdong Hua, The Effects Analysis of Counterpart Support to the Equalization of Basic Public Services: Taking Earthquake-Stricken Areas of Sichuan as a Case [Duikou Zhiyuan Cujin Jiben Gonggong Fuwu Zhundenghua Xiaoying Fenxi], 5 Xi'an Caijing Xueyuan Xuebao [Journal of Xi'an University of Finance and Economics] 75-81 (2010).

years. ${ }^{80}$ One percent is the minimum requirement of the central government, but the supporting province may increase the donation at its discretion. In fact, some provinces gave more than a 1 percent share (Table 1.4). Under the authoritarian regime, political benefit is an important incentive for the supporting provinces' governors to increase the counterpart aid capital. ${ }^{81}$ Under China's authoritarian regime, the political selection of officers depends on a competitive political tournament. Therefore, the governors of provinces have incentives to perform better in counterpart aid to win support from/attract the attention of the central government.

In short, counterpart aid can be regarded as a special "pooling" of catastrophe risk because it spreads specific natural disaster risk across selected provinces and improves social welfare. This mechanism differs from a central fund, which would require every province to give

80 Y.-M. Wei, J.-L. Jin and Q. Wang, Impacts of Natural Disasters and Disasters Risk Management in China: The Case of China's Experience in Wenchuan Earthquake in Economic and Welfare Impacts of Disasters in East Asia and Policy Responses 641 (Y. Sawada and S. Oum eds., 2012).

81 See Lian Zhou, Administrative Subcontract [Xizheng Fabaozhi], 6 Society [Shehui] 1 (2014). 
1 percent to a fund that could then be used across victimized areas. Counterpart aid linking donor and recipient areas in this way seems economically pointless, since it only imposes unneeded constraints on the flow of funds. However, due to China's unusual size and regional diversity, especially the huge economic imbalance among different provinces - for example, the GDP of the richest province in 2014 is 77 times that of the poorest ${ }^{82}$-requiring the richer provinces to contribute more in disaster relief emphasizes the concern for equality rather than economic efficiency.

\section{People relying on and trusting in the government}

Given the history of a planned economy, people in China still have a strong reliance on government, especially in the aftermath of a catastrophe. According to a nationwide survey in China that covered 856 cities and counties in 2009, when asked, "Who should take the major responsibility to undertake the burden of disaster losses and pay the bill?" nearly 70 percent of respondents indicated that government should take the major responsibility and cover disaster losses, while only 6.6 percent believed community or individual families should be responsible. ${ }^{83}$ Under the leadership of the government, the Whole-Nation System accords with preferences for relying on government to deal with catastrophes.

A lack of public trust would undermine the credibility and stability of the Whole-Nation System, and lead to inefficiency, unrest, or even failure. ${ }^{84}$ Only if the government enjoys high levels of trust can it gain space and freedom to act and have the opportunity to prove that its actions are in the interests of the people. ${ }^{85}$

Under the authoritarian Chinese regime, natural disasters provide unique opportunities for government to show its responsibility and

82 China GDP Ranking among Provinces in 2014, available at http://www. mnw.cn/news/cj/715060.html.

83 Ming Wang, Chuan Liao, Saini Yang, Weiting Zhao, Min Liu and Peijun Shi, Are People Willing to Buy Natural Disaster Insurance in China? Risk Awareness, Insurance Acceptance, and Willingness to Pay, 32 Risk Analysis 1717 (2012).

84 K. Dalen, H. Flatø, L. Jing and Z. Huafeng, Recovering from the Wenchuan Earthquake. Living Conditions and Development in Disaster Areas 2008-2011, 39 (Oslo: FAFO, 2012).

85 Jan Delhey and Kenneth Newton, Social trust: global pattern or Nordic exceptionalism? Discussion paper for Wissenschaftszentrum Berlin für Sozialforschung (WZB) (2004). 
accountability to the people. ${ }^{86}$ Therefore, the government has strong incentives to perform well and increase people's loyalty through the Whole-Nation System. In addition, it is easier for China to deliver disaster relief efficiently because, unlike the United States with its federal system, China is a unitary state in which the central government has absolute impact on the performance of the local governments. ${ }^{87}$ During disaster relief, local governments are not only supported but also supervised by the central government. This system has facilitated the operation of the Whole-Nation System, especially counterpart aid.

\section{A short conclusion}

Under the Whole-Nation System, China's government has unique resources at its disposal to manage the disaster response and recovery processes. It coordinates multiple levels of government and establishes national pools. It also mobilizes the military for emergency response to disasters. Though by no means a perfect risk manager, the Chinese government does take up the vacuum, as Nobel economist Kenneth Arrow suggested in another context, to "undertake insurance in those cases where [a private market for insurance], for whatever reason, has failed to emerge". 88

\section{The Problems with the Whole-Nation System}

Now we are ready to ask whether the Whole-Nation System can possibly do any better than private insurance, which has already demonstrated significant market failures in covering catastrophe risk. As will become clear, the answer is a resounding "yes" in theory but a tantalizing "no" in reality. In fact, the government is by no means a perfect risk manager. Just as even the best market systems confront "market failures", government solutions confront many obstacles and problems, collectively known as "government failures". The Whole-Nation System is no exception.

According to surveys conducted after the 2008 Great Sichuan

86 Y.A. Lazarev, A.S. Sobolev, I.V. Soboleva and B. Sokolov, Trial by Fire: A Natural Disaster's Impact on Support for the Authorities in Rural Russia, 66 World Politics 641 (2014) (The legitimacy of government depends on not only its economic performance but also its response and accountability to the people. The impact of natural disasters on support for authorities is conditional on governmental performance during and after the event).

87 Lian Zhou, Administrative Subcontract [Xizheng Fabaozhi], 6 Society [Shehui] 1 (2014).

88 Kenneth Arrow, Uncertainty and the Welfare Economics of Medical Care, 53 The American Economic Review 941(1963). 


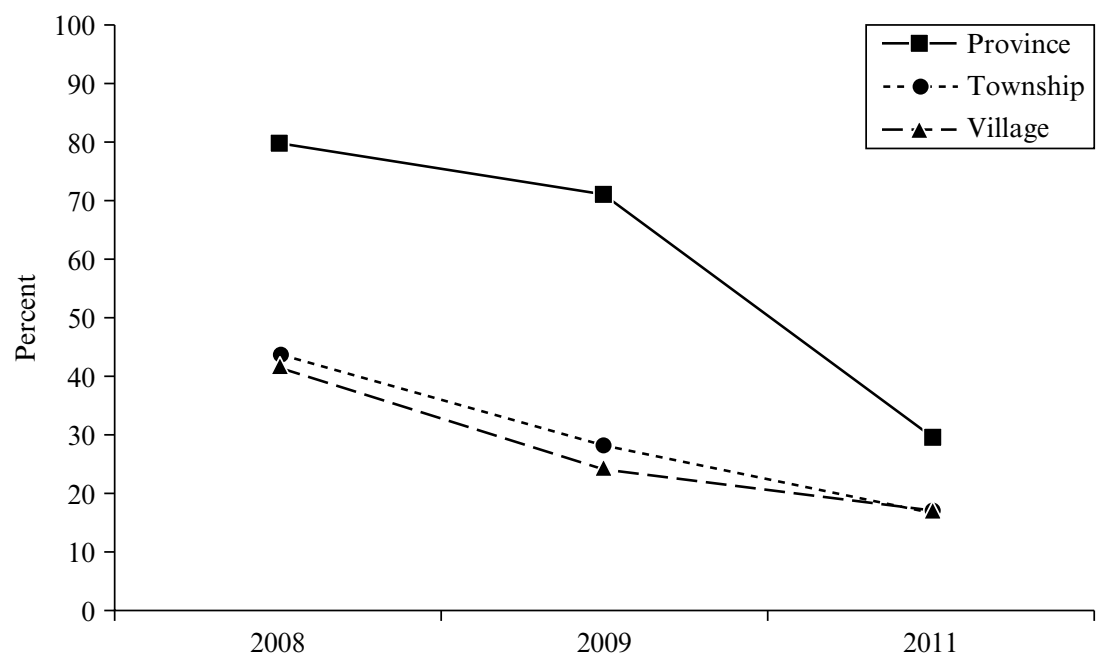

Source: K. Dalen, H. Flatø, L. Jing and Z. Huafeng, Recovering from the Wenchuan Earthquake. Living Conditions and Development in Disaster Areas 2008-2011, 175 (Oslo: FAFO, 2012).

Figure 1.3 Declining satisfaction with government relief after the 2008 Great Sichuan Earthquake

Earthquake, the degree of satisfaction with all levels of government (except the central government) had declined since the quake (Figure 1.3). The criticism of government relief grew over time. ${ }^{89}$

Added to the above discussion of how the Whole-Nation System worked during the 2008 Great Sichuan Earthquake must be an examination of some of its many problems, especially over the long run.

- The perverse incentives for rent-seeking and corruption

- Samaritan's Dilemma reducing people's incentives to invest in protection and mitigation measures

- The regressive effects of counterpart aid

- The lack of risk financing under the Whole-Nation System

- The burden on public budgets and possible hindrance to economic growth

- The overuse of the military's resources for nondefense purposes

89 K. Dalen, H. Flatø, L. Jing and Z. Huafeng, Recovering from the Wenchuan Earthquake. Living Conditions and Development in Disaster Areas 2008-2011, 175 (Oslo: FAFO, 2012). 


\section{Corruption problems}

Before the economic reform and opening, corruption tended to be visible and easy to prevent because officials normally had only a single income source under the planned economy. ${ }^{90}$ However, corruption problems became more serious and rampant when China decided to transit from a planned to a market economy. While the government remains as powerful as it has always been, the market-oriented reforms create substantially greater rent-seeking opportunities. ${ }^{91}$ As a result, officials at every level have found many sources of income beyond a single government salary. ${ }^{92}$ Officials who implement the Whole-Nation System are not easily immunized from corruption problems. In fact, increasing government aid under the Whole-Nation System may create more corruption opportunities than before.

There were several different forms of corruption among local officials in the wake of the 2008 Great Sichuan Earthquake. One form was the embezzlement or misuse of relief funds. The central government sent funds to various agencies in Sichuan Province after the earthquake. Although that money was intended for relief, significant amounts ended up paying for government banquets and officials' bonuses. ${ }^{93}$ Another example of the embezzlement of relief funds was the case of a secondary school built in 2010 with quake relief funds, which was later torn down to make way for luxury houses. ${ }^{94} \mathrm{~A}$ second form of corruption is the misappropriation

\footnotetext{
90 Justin Yifu Lin, Demystifying the Chinese Economy 19 (2012).

91 China's economic transition process is known as the "dual-track system" which differs from "shock therapy". The dual-track system refers to the process of moving from a single track, planned economic system to a combination system and finally to the single track of a market system. Under the dual-track system, market prices of goods during the transition are higher than the planned prices because planned prices are artificially suppressed by the government. Furthermore, government regulates market access to placate "legacy" suppliers. These market distortions too often lead to rent-seeking and corruption. See Justin Yifu Lin, Demystifying the Chinese Economy 194-198 (2012).

92 For example, officials have the power to grant permits for a variety of businesses such as land acquisitions and construction. They may ask for direct payments but also shares in the company, property at below-market price, lavish dinners, and so on. Such practices are so widespread, and so many officials and their family members are involved, that those corruption problems are extremely difficult to solve. See Ezra F. Vogel, Deng Xiaoping and the Transformation of China 712 (2011).

93 He Wang, Research on Catastrophe Risk Insurance Mechanisms 92-93 (2013).

94 He Wang, Research on Catastrophe Risk Insurance Mechanisms 92-93 (2013).
} 
or misuse of disaster goods. In Deyang, a city in Sichuan affected by the earthquake, an officer stole 10 containers of earthquake relief goods rather than send them to homeless residents. ${ }^{95}$ Furthermore, some tents marked "disaster only" appeared on some officers' upscale patios, which had been barely touched by the quake. ${ }^{96} \mathrm{~A}$ third form of corruption occurred when officials secretly granted reconstruction projects to their friends and family members without due process or transparency. According to the earthquake relief audit report of the National Audit Office of the PRC, there were 146 of these cases in Sichuan in 2008, totaling \$220 million. ${ }^{97}$

Unfortunately, corruption problems were much worse in the long run under the Whole-Nation System than short-run emergency relief. The relief and reconstruction funds from the central government were allocated to local governments, and local governments were requested to take responsibility for implementation. ${ }^{98}$ In the early days after the disaster, almost all government relief programs were under the spotlight of the whole nation, not only the central government but also the media. Public response to disasters is in proportion to media coverage. As is common throughout the world, media coverage surges upward in the immediate aftermath of a disaster, throwing a bright spotlight on the victims, and then attention quickly dissipates. ${ }^{99}$ Under these circumstances, it is difficult for local officials to divert disaster aid.

However, as time passed and the media spotlight shifted, national attention was diverted. As a result, although the total accumulated capital for disaster relief was high, the central government leaders' focus on the disaster was short-lived. ${ }^{100}$ This short time horizon weakened public and

95 China Earthquake Brings Corruption, Relief Suspicion, USA Today (May 29, 2008), available at http://usatoday30.usatoday.com/news/world/2008-05-29china-corruption_N.htm.

${ }_{96}$ China Earthquake Brings Corruption, Relief Suspicion, USA Today (May 5, 2008), available at http://usatoday30.usatoday.com/news/world/2008-05-29-chinacorruption_N.htm.

97 He Wang, Research on Catastrophe Risk Insurance Mechanisms 92 (2013).

98 Jiang Lingling et al., People's Republic of China: Providing Emergency Response to Sichuan Earthquake, Technical Assistance Consultant's Report to Ministry of Civil Affairs, P.R. China and Asian Development Bank (2008).

99 David A. Moss, The Peculiar Politics of American Disaster Policy: How Television has Changed Federal Relief in The Irrational Economist 151 (Erwann Michel-Kerjan and Paul Slovic eds., 2010).

100 David A. Moss, The Peculiar Politics of American Disaster Policy: How Television has Changed Federal Relief in The Irrational Economist 151 (Erwann Michel-Kerjan and Paul Slovic eds.2010). For example, then-premier Wen Jiabao arrived at the affected areas to command disaster relief just eight hours after the 2008 Sichuan Earthquake. However, after less than a month, he had to go back to 
media oversight of local government disaster relief work. When local officers were the only ones who knew what was going on, they were tempted to abuse their power and exploit victims. ${ }^{101}$

This problem is not specific to China. Any system involving distributing large sums of money is vulnerable to dishonest contractors and corrupt officials. As every government learns after disasters, money corrupts. ${ }^{102}$

\section{The Samaritan's Dilemma}

The Samaritan's Dilemma ${ }^{103}$ haunts governmental aid. According to James Buchanan's definition, the Samaritan's Dilemma is created when the government makes direct payments to individuals after a disaster, giving them incentives not to take protective measures or purchase insurance but instead to rely on the government to bail them out. ${ }^{104}$ Even if the government promises ex ante not to provide such relief, the promise is not credible, because it will be in everyone's interests to offer such relief after a disaster has struck. ${ }^{105}$ Therefore, more government bailouts may cause more disaster losses because people are less likely to take precaution measures. ${ }^{106}$

The Whole-Nation System poses the Samaritan's Dilemma. Often, a government bailout is motivated by an admirable humanitarian impulse that spurs redistributing wealth to those who have suffered loss from those who have been spared. ${ }^{107}$ Political concerns are also important under the Whole-Nation System. Although the Chinese central government has no re-election constraints, governmental performance in providing relief during and after the disaster impacts the support for the authorities at all

Beijing to deal with other national affairs and paid less and less attention to earthquake relief after the emergency work was accomplished. See Wen Jiabao: Please Remember the Great Sichuan Earthquake, China News (May 24, 2008), available at http://www.chinanews.com/gn/news/2008/05-24/1260997.shtml.

101 Justin Yifu Lin, Demystifying the Chinese Economy 198 (2012).

102 Katrina: Four Years Later-Fraud, Corruption Cases Continue (Federal Bureau of Investigation, 2009), available at http://www.fbi.gov/news/stories/2009/ september/katrina_090109.

103 It is based on an old parable of the traveler from Samaria who helped a stranger whom he found beaten and robbed by the side of the road.

104 James M. Buchanan, The Samaritan's Dilemma in Altruism, Morality and Economic Theory 71 (E.S. Phelps ed., 1972).

105 James M. Buchanan, The Samaritan's Dilemma in Altruism, Morality and Economic Theory 71 (E.S. Phelps ed., 1972).

106 Tom Baker, On the Genealogy of Moral Hazard, 75 Texas Law Review 237 (1996).

107 George L. Priest, Government Insurance versus Market Insurance, 28 The Geneva Papers on Risk and Insurance-Issues and Practice 71 (2003). 
levels. ${ }^{108}$ However, this humanitarian and political action ignores the fact that in some cases, the effect of the redistribution will encourage future loss-causing activities that would not otherwise have been undertaken. ${ }^{109}$ Some pure forms of government bailout, including ad hoc direct payment and compensation funds, provide insufficient incentives for risk prevention and loss mitigation. ${ }^{110}$ Therefore, individuals will be less inclined to protect against disaster when they believe the government will bail them out, which increases the magnitude of loss for the whole nation.

In addition, the Chinese people have historically had a strong inclination to rely on a governmental bailout in the wake of a catastrophe. Under the Whole-Nation System, the government is committed to restoring social and economic order after a disaster. Thanks to such governmental commitment, individuals' personal experiences, and media reports of past catastrophes, it is rational for the Chinese people to fail to take adequate protective measures. Many residents admit that they are exposed to catastrophe risks, but they seldom transfer risks through insurance because they believe the government will bail them out when catastrophes happen. ${ }^{11}$ According to an empirical study on property and causality insurance in five Chinese provinces, there is a negative correlation between the amount of government relief and residents' investment in prevention measures such as purchasing insurance. ${ }^{12}$

In short, the Samaritan's Dilemma, which reduces individuals' incentives to invest in protective measures and leads to further government bailouts, is a challenge for the Whole-Nation System. ${ }^{113}$

108 Egor Lazarev, Anton Sobolev, Irina V. Soboleva and Boris Sokolov, Trial by Fire: A Natural Disaster's Impact on Support for the Authorities in Rural Russia, 66 World Politics 641 (2014).

109 George L. Priest, Government Insurance versus Market Insurance, 28 The Geneva Papers on Risk and Insurance-Issues and Practice 71 (2003).

110 Roger Van den Bergh and Michael Faure, Compulsory Insurance of Loss to Property Caused by Natural Disasters: Competition or Solidarity?, 29 World Competition 25 (2006).

111 He Wang, Research on Catastrophe Risk Insurance Mechanisms 5 (2013).

112 L. Tian and Y. Zhang, Influence Factors of Catastrophe Insurance Demand in China-Panel Analysis in a Case of Insurance Premium Income of Five Provinces [Woguo Juzai Baoxian Xuqiu Yingxiang Yinsu Shizheng Yanjiu: Jiyu Wusheng Bufen Baofei Shouru Mianban Yanjiu], 26 Wuhan University of Technology (Social Science Edition) [Wuhan Ligong Daxue Xuebao (Shehui Kexue Ban)] 175 (2013).

113 James M. Buchanan, The Samaritan's Dilemma in Altruism, Morality and Economic Theory 71 (E.S. Phelps ed., 1972). 
Table 1.5 Comparison between some supporting provinces and supported counties in per capita fiscal expenditure before the 2008 earthquake (RMB)

\begin{tabular}{lclc}
\hline $\begin{array}{l}\text { Supporting } \\
\text { provinces or } \\
\text { municipalities }\end{array}$ & $\begin{array}{c}\text { Per capita fiscal } \\
\text { expenditure (2007) }\end{array}$ & Supported counties & $\begin{array}{c}\text { Per capita fiscal } \\
\text { expenditure (2007) }\end{array}$ \\
\hline Hunan & 2,135 & Lixian County & 4,209 \\
Jilin & 3,237 & Heishui County & 4,149 \\
Anhui & 2,033 & Songpan County & 4,107 \\
Jiangxi & 2,072 & Xiaojin County & 3,056 \\
\hline
\end{tabular}

Source: Ni, Feng, Zhang, Yue, and Yu, Tongzhou, Wenchuan Dadizhen Duikou Zhiyuan Chubu Yanjiu [Preliminary Research on Counterpart Aid of Wenchuan Earthquake], 7 Jingji Guanli Yu Yanjiu [Research on Economics and Management] 55-62 (2009).

\section{The regressive effects of counterpart aid}

Counterpart aid is a mechanism within the Whole-Nation System under which the central government organizes a special "pooling" of catastrophe risk across the country. It relies on the maxim that "one province helps one significantly affected county", in theory requiring the richer provincesnot all provinces - to help disaster-affected areas and contribute more in disaster relief. However, when the disaster is a widespread catastrophe and many counties are affected, this "one province helps one significantly affected county" arrangement frequently leads to the situation in which not-that-rich provinces have to help reconstruct richer (by per capita fiscal expenditure) counties. For example, Hunan Province was responsible for the reconstruction of Lixian County after the Great Sichuan Earthquake. However, the per capita fiscal expenditure of Hunan Province was only RMB 2,135 in 2007; of Sichuan Province, RMB 2,165; and of Lixian County, RMB 4,209. ${ }^{114}$ Similar per capita disparities existed in Jilin, Anhui, and Jiangxi provinces (Table 1.5).

Counterpart aid aims to realize the goal of "common prosperity" through richer provinces helping poorer ones. In practice, however, sometimes poorer provinces have to help richer ones. Adding to the problem is that there are no legal provisions regulating counterpart aid, which means

114 Feng Ni, Yue Zhang and Tongzhou Yu, Wenchuan Dadizhen Duikou Zhiyuan Chubu Yanjiu [Preliminary Research on Counterpart Aid of Wenchuan Earthquake], 7 Jingji Guanli Yu Yanjiu [Research on Economics and Management] 55 (2009). 
that the obligations of supporting provinces are unclear and arbitrary and decided at the discretion of the central government. ${ }^{115}$

Sometimes, the counterpart aid arrangement has not followed the principle of equality or efficiency but has resulted from political pressure. For example, after the Xinjiang Riot in 2009, one year later, 19 provinces were required to supply counterpart aid to Xinjiang Uygur Autonomous Region (hereinafter "Xinjiang") for its reconstruction and development just as was required for post-disaster restoration and reconstruction of the Great Sichuan Earthquake. ${ }^{116}$ The per capita GDP of some supporting provinces was lower than that of Xinjiang. ${ }^{117}$ Three years later, more supporting provinces, including Hunan, Henan, and Shanxi, were still lower than Xinjiang in per capita GDP. From this perspective, the Whole-Nation System perpetuates inequality, and the regressive effects of counterpart aid are more severe.

Even when poor areas suffer from catastrophe losses, unfairness may arise. For example, after the 2008 Great Sichuan Earthquake, Shandong Province, which ranked in the top three in GDP in 2007, was responsible for the reconstruction of BeiChuan County and donated RMB 12 billion (about $\$ 2$ billon). ${ }^{118}$ The per capita fiscal expenditure of Shandong Province was RMB 2,415 in 2007, while in Beichuan County it was RMB 2,299. ${ }^{119}$ Five years later, however, after receiving the counterpart aid, BeiChuan County

115 L. Zhao and Y.J. Jiang, Analysis of Local Government Coordinated Assistance Modes [Difang Zhengfu Duikou Zhiyuan Moshi Fenxi], 2 Journal of ChengDu University (Social Science Edition) [ChengDu Daxue Xuebao (Sheke Ban)] 4, 25 (2009).

116 Xlong Wenzhao and Tian Yan, Research on the Legalization of Partner Assistance Policy in Xinjiang [Duikou Yuanjiang Zhengce De Fazhihua Yanjiu], 31 Journal of Xinjiang Normal University (Social Science) [Xinjiang Shifan Daxue Xuebao (Shehui Kexue Ban)] 12 (2010).

117 Per capital GDP of Jiang Xi province (RMB 21,288) and An Hui province (RMB 20,002) are lower than Xinjiang (RMB 23,159). See Xlong Wenzhao and Tian Yan, Research on the Legalization of Partner Assistance Policy in Xinjiang [Duikou Yuanjiang Zhengce De Fazhihua Yanjiu], 31 Journal of Xinjiang Normal University (Social Science) [Xinjiang Shifan Daxue Xuebao (Shehui Kexue Ban)] 12 (2010).

118 L. Zhao and Y.J. Jiang, Analysis of Local Government Coordinated Assistance Modes [Difang Zhengfu Duikou Zhiyuan Moshi Fenxi], 2 Journal of ChengDu University (Social Science Edition) [ChengDu Daxue Xuebao (Sheke Ban)] 4, 25 (2009).

119 Feng Ni, Yue Zhang, and Tongzhou Yu, Wenchuan Dadizhen Duikou Zhiyuan Chubu Yanjiu [Preliminary Research on Counterpart Aid of Wenchuan Earthquake], 7 Jingji Guanli Yu Yanjiu [Research on Economics and Management] 55 (2009). 
was much more prosperous than many Shandong Province counties. ${ }^{120}$ In 2012, the per capita fiscal expenditure in Shandong Province was around RMB 5,900, while in Beichuan County it was around RMB 8,000. ${ }^{121}$

In fact, counterpart aid does not eliminate risk but only distributes the burden of disaster losses across the taxpayers of supporting provinces. Therefore, counterpart aid emerges as an arguably unfair arrangement for the residents of the supporting provinces because the supporting provinces may treat their own residents "less favorably" than those in disaster areas. Under China's political selection system, in which the central government has the final word rather than the residents, ${ }^{122}$ governors of supporting provinces have strong incentives to deal with disaster-affected areas more favorably than they do with their own residents because the counterpart aid is politically favored by the central government.

\section{Lack of risk financing}

Risk financing is regarded as one of the three pillars of risk management and classically requires those who face risks to pay for coverage through risk-based premiums. ${ }^{123}$ Ex ante insurance with risk-based premiums provides incentives to accumulate reserves and mitigate losses before disasters, while ex post government aid may reduce incentives to reserve funds or carry out mitigation activities. ${ }^{124}$ The Whole-Nation System pays little attention to, and indeed lacks, the capability of risk financing through ex ante insurance markets to compensate victims, instead focusing on ex post relief. To illustrate, of the compensation for the Great Sichuan Earthquake, only $\$ 300$ million of the losses were covered by insurance companies, i.e., only 0.3 percent of the total losses incurred. ${ }^{125}$

120 He Wang, Research on Catastrophe Risk Insurance Mechanisms 86 (2013).

121 Annual Fiscal Report of Beicuan County (2012), available at http://www. beichuan.gov.cn/htm1/2013/gsgg_0529/10227.html?cid=11; Annual Fiscal Report of Shandong Province (2012), available at http://www.mof.gov.cn/zhuantihuigu/20 13ssyshb/201302/t20130219_733742.html.

122 Lian Zhou, Administrative Subcontract [Xizheng Fabaozhi], 6 Shehui [Society] 1 (2014).

123 F. Outreville, Theory and Practice of Insurance 45-64 (1998); R. Thoyts, Insurance Theory and Practice 286-295 (2010). (The other two are risk assessment (also known as risk analysis) and risk control).

124 Dwight Jaffee and Thomas Russell, The Welfare Economics of Catastrophe Losses and Insurance, 38 The Geneva Papers on Risk and Insurance-Issues and Practice 469 (2013).

125 Establishing Catastrophe Insurance System Faces Acceleration, China Youth Daily (March 14, 2011), available at http://zqb.cyol.com/html/2011-03/14/ nw.D110000zgqnb_20110314_1-05.htm?div=-1. 
Furthermore, aspects of the Whole-Nation System, such as counterpart aid, "crowd out" the establishment and development of risk financing markets by depressing the demand of individuals for catastrophe insurance. Individuals are less likely to purchase insurance to prefinance their potential disaster losses. According to general international experiences, a catastrophe insurance system is often established within two years after a disaster occurs. For example, in 1944, after the 1942 earthquake in New Zealand, an earthquake insurance system was established. ${ }^{26}$ California's experience was similar. ${ }^{127}$ However, five years after the 2008 Great Sichuan Earthquake, a catastrophe insurance market had not yet been officially established in China. The Whole-Nation System, which played a powerful role in earthquake relief, at least partially accounts for this.

\section{Other challenges and problems}

Besides the above problems of the Whole-Nation System, there are other potential challenges.

Disaster relief imposes burdens on public budgets and may hinder economic growth. In smaller and developing countries, a catastrophe event can result in higher public deficits and debt. ${ }^{128}$ Although China is now the second largest economy in the world, the cost of the Whole-Nation System still imposes a considerable burden on the public budget. For example, the government spent approximately $\$ 166$ billion after the 2008 earthquake in restoration and reconstruction. ${ }^{129}$ Despite that, there is no consensus on whether disaster relief depresses or in fact enhances economic growth. ${ }^{130}$ A two-period equilibrium model indicates that direct payment of disaster relief funds may depress rather than enhance economic growth because

126 D.J. Dowrick, Damage and Intensities in the Magnitude 7.8 1929 Murchison, New Zealand, Earthquake, 27 Bulletin of the New Zealand National Society for Earthquake Engineering 190 (1994); D.J. Dowrick, Earthquake Risk Reduction Actions for New Zealand, 36 New Zealand Society for Earthquake Engineering 249 (2003).

127 Dwight Jaffee and T. Russell, Behavioral Models of Insurance: The Case of the California Earthquake Authority, University of California-Berkeley Working Paper (2000).

128 Swiss Re, Disaster Risk Financing: Reducing the Burden on Public Budgets, Swiss Re Focus Report (2008).

129 The total fiscal revenues were around \$1 trillion in 2008. See Jiang Lingling et al., People's Republic of China: Providing Emergency Response to Sichuan Earthquake, Technical Assistance Consultant's Report to Ministry of Civil Affairs, P.R. China and Asian Development Bank (2008).

130 Xian Xu and Jiawei Mo, The Impact of Disaster Relief on Economic Growth: Evidence from China, 38 The Geneva Papers on Risk and Insurance-Issues and Practice 495 (2013). 
disaster relief related to the loss of capital and the substitution effect of direct transfer payment depresses post-disaster labor supply. ${ }^{131}$ Such effects of disaster relief on growth have been tested using panel data on 31 Chinese provinces, municipalities, and autonomous regions over the period 2004-2010. ${ }^{132}$ The extensive use of the military in disaster relief has been a double-edged sword because it could potentially displace the development of an effective civilian-based disaster management system in the future. ${ }^{133}$

In addition, the Whole-Nation System leads to an unstable budget because it operates as an ad hoc compensation tool for victims, which may dampen economic growth.

The misappropriation of funds or goods also contributes to the negative impact of the Whole-Nation System. According to a survey report in earthquake-affected areas after the 2008 Great Sichuan Earthquake, the Ministry of the Civil Affairs was in charge of medical aid money, while the Ministry of Health was responsible for patients' treatment. This mismatch of rights and obligations between different departments increases transaction costs but also leads to the misuse of capital and medical resources. ${ }^{134}$

\section{E. A Short Conclusion}

After considering the structure of the Whole-Nation System, how it works, and its problems, we may see that the Whole-Nation System has indeed played a valuable role in dealing with catastrophe losses in China. More important insights for the Whole-Nation System, however, suggest opportunities for improvement. Summarized in Figure 1.4, the System's pre-disaster measures as ex ante mitigation actions are efficient policies to address catastrophe losses, as are its post-disaster measures in emergency response.

Figure 1.4 also shows the problems of the Whole-Nation System. What the System did in pre-disaster measures is too little, not too much. For

131 F. Barry, Government Consumption and Private Investment in Closed and Open Economies, 21 Journal of Macroeconomics 93 (1999); T. McDermott, F. Barry and R. Tol, Disasters and Development: Natural Disasters, Credit Constraints and Economic Growth, ESRI Working Paper No. 411 (2011).

132 Xian Xu and Jiawei Mo, The Impact of Disaster Relief on Economic Growth: Evidence from China, 38 The Geneva Papers on Risk and Insurance-Issues and Practice 495 (2013).

133 Jian Zhang, The Military and Disaster Relief in China: Trends, Drivers and Implications in Disaster Relief in the Asia Pacific: Agency and Resilience (Minako Sakai et al. eds., 2014).

134 He Wang, Research on Catastrophe Risk Insurance Mechanisms 92 (2013). 


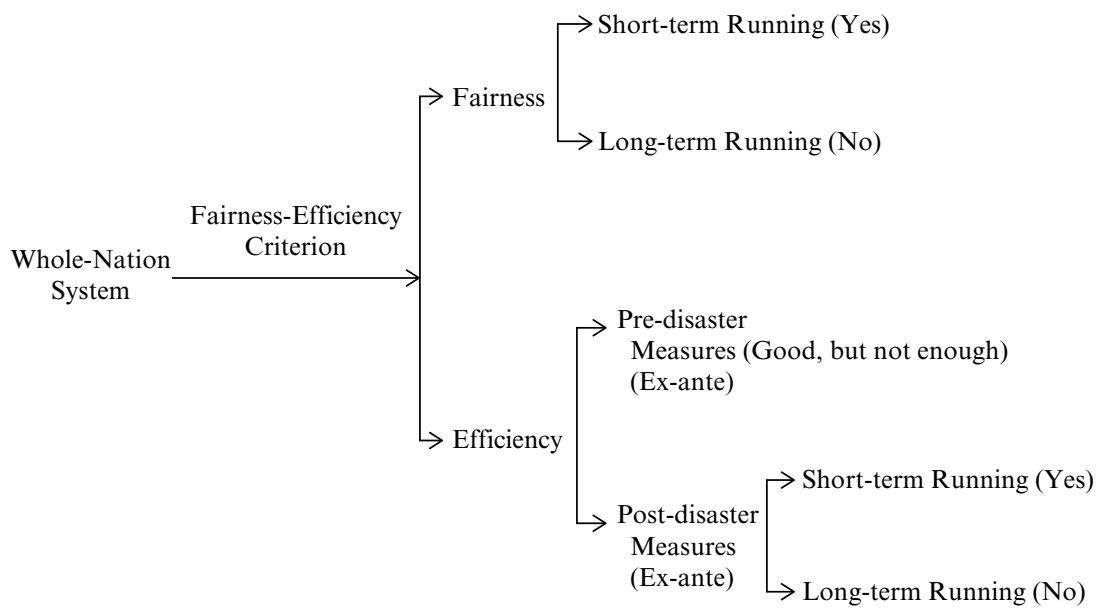

Figure 1.4 Evaluation of the Whole-Nation System

actions post-disaster, there should be a close examination of the methods of victims' compensation and counterpart aid.

The Whole-Nation System, in this limited context, seems to have performed reasonably well, but it is far from a totally efficient, sustainable, and long-term catastrophe risk management system. Although private insurance must deal with various market failures in covering catastrophe risks, it is difficult to say that the Whole-Nation System is superior to catastrophe insurance. To deal with the risk of natural disasters more effectively in China, there is an urgent need for the reform of the WholeNation System to integrate it with insurance that could finance underlying catastrophe risks and offer other advantages. Two methods will be proposed. One is the government stimulation of private catastrophe insurance (the following section and Chapter 2, 3 and 4), and the other is government sponsored reinsurance to finance and support primary catastrophe insurance due to market failure (Chapter 5). Such a reform could improve social welfare and advance social justice.

\section{GOVERNMENT STIMULATION OF PRIVATE CATASTROPHE INSURANCE MARKETS FOR DISASTERS}

Having reviewed the performance of the Whole-Nation System-its achievements and problems - we are now ready to explore its reform and 
transition. Compared with the government-run Whole-Nation System, insurance is traditionally recognized as an important tool to deal with catastrophic disasters, "through risk pooling and risk shifting, but also risk reduction and risk management". ${ }^{135}$ Moreover, many law and economics scholars favor insurance as a private-market mechanism for distributing catastrophe risk, especially when compared to government-provided compensation. ${ }^{136}$ For example, Jaffe and Russell, ${ }^{137}$ Kunreuther, ${ }^{138}$ Epstein, ${ }^{139}$ Priest, ${ }^{140}$ and $\mathrm{Kaplow}^{141}$ argue that insurance is better equipped to deal with catastrophe risks than the government due to its advantages of lower transaction costs, lower adverse selection, and greater efficiency. MichelKerjan et al. posit that as the level of economic development improves within a state, public and private catastrophe insurance should gradually develop (Figure 1.5). ${ }^{142}$ According to this simplified view, China should be moving from step 2 to step 3 , consistent with the observation that catastrophe insurance could be a necessary and proper complement to the WholeNation System. Before the discussion of insurance's role in addressing catastrophe losses, ${ }^{143}$ however, the starting point should be how to create a catastrophe insurance market in China where, for whatever reason, it has still failed to emerge.

135 Omri Ben-Shahara and Kyle D. Logue, Outsourcing Regulation: How Insurance Reduces Moral Hazard, 111 Michigan Law Review 197 (2012).

136 Michael Faure and Klaus Heine, Insurance Against Financial Crises?, 8 NYU Journal of Law \& Business 117 (2011).

137 Dwight Jaffe and Thomas Russell, Catastrophe Insurance, Capital Markets, and Uninsured Risks, 62 Journal of Risk and Insurance 205 (1997).

138 Howard Kunreuther, The Case for Comprehensive Disaster Insurance, 11 Journal of Law and Economics 133 (1968).

139 Richard A. Epstein, Catastrophe Responses to Catastrophe Risks, 12 Journal of Risk and Uncertainty 287 (1996).

140 George L. Priest, The Government, the Market, and the Problem of Catastrophe Loss, 12 Journal of Risk and Uncertainty 219 (1996).

141 Louis Kaplow, Incentives and Government Relief for Risk, 4 Journal of Risk and Uncertainty 167 (1991).

142 "Level 1: Very limited funding from central government; heavy reliance on donors; Level 2: Mainly ex-post funding from the central government; Level 3: Some coverage by insurance systems; government is still the main funding source; Level 4: Significant (re)insurance penetration; government supplements by allocating catastrophic risk capital”. See Erwann Michel-Kerjan et al., Catastrophe Financing for Governments: Learning from the 2009-2012 MultiCat Program in Mexico, OECD Working Papers on Finance, Insurance and Private Pensions, No. 9 (2011).

143 This will be discussed in Chapter 2. 


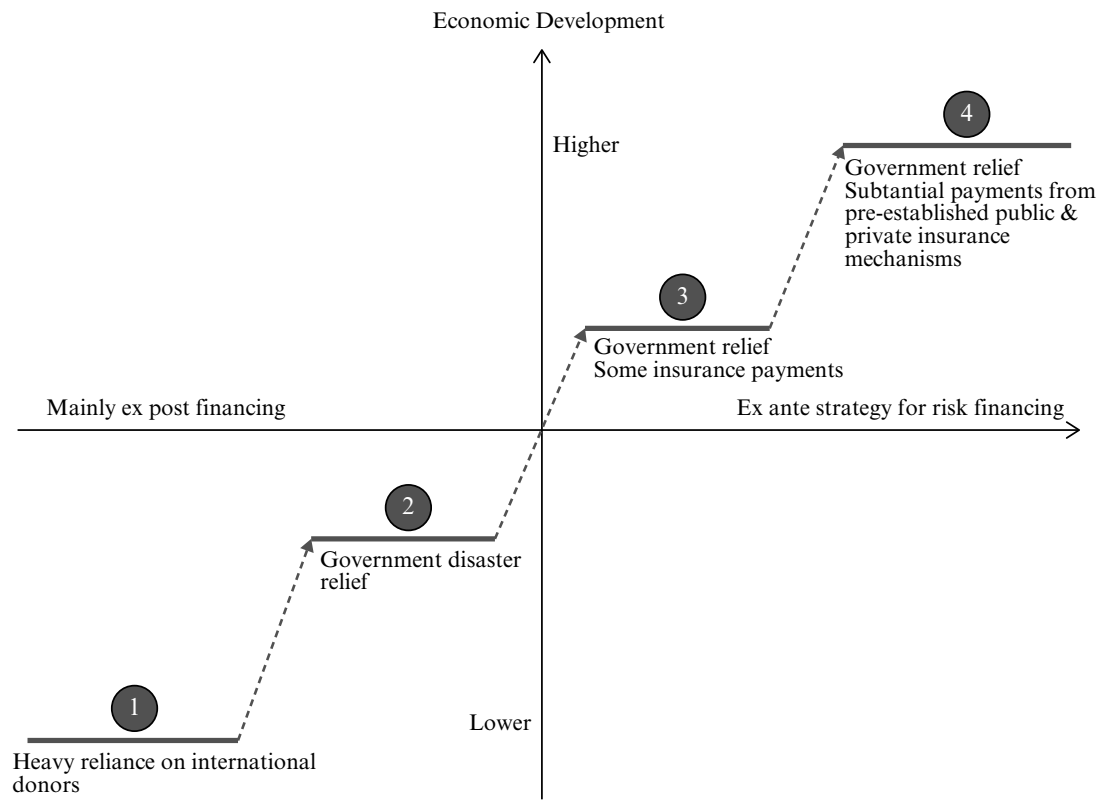

Source: Erwann Michel-Kerjan, et al., Catastrophe Financing for Governments: Learning from the 2009-2012 MultiCat Program in Mexico, OECD Working Papers on Finance, Insurance and Private Pensions, No. 9, (2011).

Figure 1.5 A simplified view of governments' responses to financial management of natural disasters

\section{A. The Immature Catastrophe Insurance Market in China}

In 1959, the Chinese government closed all domestic insurance companies, and the insurance business as a whole virtually disappeared from 1959 to 1978. ${ }^{144}$ After the Third Plenum of the Eleventh Party Congress, the process of institutional transformation towards a market-oriented economy began, and commercial insurance agencies also resumed doing business. In 1979, the State Council approved the "Notice on Restoration of the Domestic Insurance Business and Strengthening of the Insurance Agency" (Guanyu Huifu Guonei Baoxian Yewu He Jiaqiang Baoxian Jigou De Tongzhi), which allowed insurers to underwrite property insurance, vehicle insurance, marine insurance, and life insurance. Since 1989, the insurance industry has

144 He Wang, Research on Catastrophe Risk Insurance Mechanisms 87-89 (2013). 
been one of the fastest growing industries in China, with nominal premium income growing at an annual average rate of 30 percent. ${ }^{145}$ China's insurance market ranked as the fourth largest in the world in 2013. ${ }^{146}$

Catastrophe insurance, however, has walked a much bumpier road than other lines in the insurance industry. In 1987, the Ministry of Civil Affairs launched the agricultural insurance pilot projects in Heilongjiang, Fujian, and Jiangsu provinces. ${ }^{147}$ It is worth noting that these agricultural insurance policies covered catastrophic risks such as droughts and floods. However, these pilot projects were closed after 12 years' experimentation. ${ }^{148}$ In 1996, floods, typhoons, and other natural disasters were all prescribed as exclusions by regulators in property insurance policies. ${ }^{149}$ Thus, these catastrophic exposures were excluded from coverage under standard-form policies. As a result, in the 1998 Yangtze River flood, insurance covered only about 1.25 percent of economic losses - $\$ 500$ million coverage out of a total loss of $\$ 40$ billion. ${ }^{150}$ In 2000 , the China Insurance Regulatory Commission (CIRC) - the newly established insurance regulatory agency-prohibited insurers from underwriting earthquake insurance policies without its permission. ${ }^{151}$ As a result, only 0.3 percent of the total losses were covered by insurance companies in the 2008 Great Sichuan Earthquake. ${ }^{152}$

This earthquake underscored the need for catastrophe insurance. In

145 Bingzheng Chen, Sharon Tennyson, Maoqi Wang and Haizhen Zhou, The Development and Regulation of China's Insurance Market: History and Perspectives, 17 Risk Management and Insurance Review 241 (2013).

146 Xinhua News Agency (2013), available at http://www.gov.cn/xinwen/201407/09/content_2714415.htm.

147 Luo Guo Liang, Process and Experiences: Disaster Mitigation of New China for Sixty Years, 5 Beijing Social Science 73 (2009).

148 Peijun Shi, Di Tang, Jing Liu, Bo Chen and M.Q. Zhou, Natural Disaster Insurance: Issues and Strategy of China in Asian Catastrophe Insurance 79 (2008).

149 People's Banks of China, Notice on the Term, Rate and Provision Interpretation of $<$ Property Basic Insurance $>$ and $<$ Property Comprehensive Insurance> [Guanyu Yinfa <Caichan Baoxian Jibenxian $>$ he $<$ Caichan Baoxian Zonghexian>Tiaokuan, Feilv ji Tiaokuan Jieshi de Tongzhi] (1996), available at http://law.baidu.com/000570240002206ed685b5a29b1feb0fd7ae84890045.html.

${ }_{150}$ Ministry of the Civil Affairs of the PRC, The Statistics Report of the Civil Affairs Development [Minzheng Shiye Fazhan Baogao] (1998), available at http:// cws.mca.gov.cn/article/tjbg/200801/20080100009419.shtml.

151 CIRC, The Notice of Regulating Approving Procedure of Extended Earthquake Insurance in Enterprise Property Insurance Policy [Guanyu Qiye Chaichan Baoxian Yewu Bude Kuozhan Chengbao Dizhen Fengxian de Tongzhi] (2000), available at: http://www.chinalawedu.com/news/1200/21829/21838/2197 9/2006/3/pa1359122815161360024334-0.htm. The basis for this Regulation was concern for the solvency of insurance companies in the face of earthquake risks.

152 Establishing Catastrophe Insurance System faces acceleration, China 
2012, one of the main topics in the Fourth National Finance Working Conference was establishing a system of catastrophe insurance. ${ }^{153}$ In 2013, the "Regulation on Agriculture Insurance" was promulgated, which included government-subsidized agricultural catastrophe insurance. ${ }^{154}$ For example, Article 8 provides that the central government should establish subsidized agricultural catastrophe insurance, and local governments are encouraged to follow and contribute to the pool; Article 17 prescribes that any insurance company that wants to underwrite an agricultural insurance policy must include catastrophe insurance coverage. The Regulation includes a provision on catastrophe insurance; however, there are no details on how the government will establish the system, how much it will subsidize policyholders, how insurers should prepare for the catastrophe insurance coverage, and many other technical questions. In 2014, catastrophe insurance program trials were begun in Shenzhen, in the Pearl River Delta (a densely populated metropolitan area and also one of the world's most disaster-prone regions), and in the Chuxiong region in the southwestern province of Yunnan, which is prone to earthquakes. ${ }^{155}$ These pilot programs have yet to be evaluated. Overall, catastrophe insurance in China is still at a very immature stage and cannot yet meet the rising demand for disaster relief. It needs proper government intervention.

\section{B. Theoretical Framework for Developing a Catastrophe Insurance Market: Overcoming the Market-Government Dichotomy and Looking for Customized Solutions}

Generally speaking, there are three major theoretical frameworks for analysing government responsibilities in market intervention: laissezfaire theory, also called the market-friendly view; public-interest theory, also called the developmental-state view; and market-enhancing

Youth Daily (March 14, 2011), available at http://zqb.cyol.com/html/2011-03/14/ nw.D110000zgqnb_20110314_1-05.htm?div=-1.

153 The National Finance Working Conference is the supreme financial conference in China, which decides on the most important financial issues, such as establishing the China Insurance Regulation Commission (CIRC) (2012), available at http://finance.ce.cn/sub/2011/jrgzhy.

154 Decree No. 619 of the State Council of the People's Republic of China (2013), available at: http://www.gov.cn/zwgk/2012-11/16/content_2268392.htm.

155 China says testing catastrophe insurance system, Reuters (August 20, 2014), available at http://www.businessinsurance.com/article/20140820/NEWS04/14082 9990?AllowView=VD13UXk1T3hDUFNCbkJiYkY1TDJaRUt0ajBR V0ErOVV HUT09\#. 
theory. ${ }^{156}$ How to develop an insurance industry generally falls into one of these three camps.

\section{Laissez-faire theory}

The laissez-faire theory of government policy believes that the efficient allocation of resources within the economy can be achieved through the market mechanism; even when markets alone are insufficient, other private-sector organizations will suffice, and the outcome still remains more efficient than government intervention. ${ }^{157}$ According to this theory, private insurance markets can achieve efficient market equilibrium, and government's role is limited to providing a fair legal environment for market transactions. ${ }^{158}$ In such an analysis, calling for government intervention in providing catastrophe insurance would be viewed as opportunistic "rent-seeking" attempts of special-interest groups to secure an ex ante wealth transfer from taxpayers. ${ }^{159}$

In many respects, this theoretical framework has merit. In the absence of distortion-inducing government intervention, the outcome of the private insurance market may remain more efficient. For example, regarding rate regulation of catastrophe insurance, government often depresses insurance rates in response to political pressure. As a result, the premium cannot reflect the real risk. Insurers can no longer cover the

156 See Masahiko Aoki, Kevin Murdock and Masahiro Okuno-Fujiwara, Beyond the East Asian Miracle: Introducing the Market-Enhancing View in The Role of Government in East Asian Economic Development: Comparative Institutional Analysis (Masahiko Aoki, Hyung-Ki Kim and Masahiro OkunoFujiwara eds., 1998); C.M. Lewis and K.C. Murdock, Alternative Means of Redistributing Catastrophic Risk in a National Risk Management System in The Financing of Catastrophe Risk 74 (K. Froot ed., 1999); J.D. Cummins and O. Mahul, Catastrophe Risk Financing in Developing Countries: Principles for Public Intervention 84-85 (2009); Veronique Bruggeman, Compensating Catastrophe Victims: A Comparative Law and Economics Approach 193-195 (2010).

157 J.D. Cummins and O. Mahul, Catastrophe Risk Financing in Developing Countries: Principles for Public Intervention 84-85 (2009); Veronique Bruggeman, Compensating Catastrophe Victims: A Comparative Law and Economics Approach 193-195 (2010).

158 Masahiko Aoki, Kevin Murdock and Masahiro Okuno-Fujiwara, Beyond the East Asian Miracle: Introducing the Market-Enhancing View in the Role of Government in East Asian Economic Development: Comparative Institutional Analysis (Masahiko Aoki, Hyung-Ki Kim and Masahiro Okuno-Fujiwara eds., 1998).

159 J.D. Cummins and O. Mahul, Catastrophe Risk Financing in Developing Countries: Principles for Public Intervention 84-85 (2009). 
variable cost of providing insurance or recoup their initial investments in providing service, and this creates an availability crisis. ${ }^{160}$ The UK's private flood insurance scheme, developed about half a century ago, offers an example of how largely private markets could work. ${ }^{161}$ Private insurance companies compensate victims in the case of flood damage. Although the British government sets standards and rules for flood protection, land-use, and flood warning, it promises to guarantee the independence of privately run compensation "schemes" according to a gentleman's agreement that defines the rights and duties of state and industry. ${ }^{162}$ The UK private flood insurance scheme has remained largely unchanged since its emergence in 1961 and has proven to be efficient and sustainable. ${ }^{163}$

However, the laissez-faire theory, in which government is considered as a black box usually unsuccessfully solving problems of markets, is largely inappropriate for dealing with the practical problems of economic development and social reform in transitional economies. ${ }^{164}$ The theory confronts the "paradox of the adjusting state": on the one hand, "the government is required to withdraw from interventions into economic activities and to perform a more passive role"; on the other hand, "economic transition and development usually require nimble and robust political authorities to implement and enforce the new market-oriented policy directives due to existing market imperfections". ${ }^{165}$ Making the government more effective so that it can solve new challenges and perform new roles in facilitat-

160 C.M. Lewis and K.C. Murdock, Alternative Means of Redistributing Catastrophic Risk in a National Risk Management System in The Financing of Catastrophe Risk 75 (K. Froot ed., 1999).

161 Michael Huber, Insurability and Regulatory Reform: Is the English Flood Insurance Regime Able to Adapt to Climate Change?, 29 The Geneva Papers on Risk and Insurance-Issues and Practice 169 (2004).

162 Michael Huber, Insurability and Regulatory Reform: Is the English Flood Insurance Regime Able to Adapt to Climate Change?, 29 The Geneva Papers on Risk and Insurance-Issues and Practice 169 (2004).

163 Michael Huber, Insurability and Regulatory Reform: Is the English Flood Insurance Regime Able to Adapt to Climate Change?, 29 The Geneva Papers on Risk and Insurance-Issues and Practice 169 (2004).

164 J. Ahrens, Governance in the Process of Economic Transformation in System Transformation in Comparative Perspective: Affinity and Diversity in Institutional, Structural and Cultural Patterns (M. Jovanovic, L. Dalgon, O. Yeon-Chean, S. Park and B. Seliger eds., 2007).

165 J. Ahrens, Governance in the Process of Economic Transformation in System Transformation in Comparative Perspective: Affinity and Diversity in Institutional, Structural and Cultural Patterns (M. Jovanovic, L. Dalgon, O. Yeon-Chean, S. Park and B. Seliger eds., 2007). 
ing private-sector coordination is of utmost importance for economic transformation and social reform. ${ }^{166}$ However, it is not explicitly included in the laissez-faire theoretical framework.

Catastrophe insurance started only recently in China. In the aftermath of the 2008 Great Sichuan Earthquake, however, a catastrophe insurance market has still not yet been officially established. ${ }^{167}$ Only recently has the government decided to intervene: some pilot programs of catastrophe insurance in the cities of Shenzhen and Ningbo have been implemented since 2014. ${ }^{168}$

Clear imperfections in the insurance market in China make it is easy to perceive why catastrophe insurance has not been quickly established since the Great Sichuan Earthquake. From the supply side, insurers face a lot of obstacles to underwriting catastrophe insurance policies, such as lack of catastrophe data to identify, quantify, and estimate the chance of disasters and to set premiums; relatively low capacity of the insurance industry; limited access to international reinsurance and capital markets; regulatory obstacles; and so forth. From the demand side, consumers do not always behave rationally and maximize their expected utility to protect themselves from catastrophe losses. Their demand for catastrophe

166 J. Ahrens, Governance in the Process of Economic Transformation in System Transformation in Comparative Perspective: Affinity and Diversity in Institutional, Structural and Cultural Patterns (M. Jovanovic, L. Dalgon, O. Yeon-Chean, S. Park and B. Seliger eds., 2007).

167 It is still not formally available, although there is coverage for some natural disasters in some property insurance policies underwritten by the People's Insurance Company of China (PICC). According to general international experiences, a catastrophe insurance system is often established within two years after a catastrophe disaster. For example, after the 1999 Marmara Earthquake in Turkey, with the support of the World Bank and Turkish government, the Turkish Catastrophe Insurance Pool (TCIP) was created in 2000. See Johann-Adrian von Lucius, A Reinsurance Perspective on the Turkish Catastrophe Insurance Pool in Catastrophe Risk and Reinsurance: A Country Risk Management Perspective 217 (Eugene N. Gurenko ed., 2004); D.M. Jaffee and T. Russell, Behavioral Models of Insurance: the Case of the California Earthquake Authority, University of California-Berkeley Working Paper (2000).

168 According to the latest news, in July 2014, the Government of Shenzhen bought a catastrophe insurance policy from PICC on behalf of the residents of Shenzhen. This catastrophe insurance framework includes three different parts: the first part is the government catastrophe assistance insurance, which was bought by the Shenzhen municipal government to supply the basic assistance for all residents; the second part is a catastrophe fund; and the third part is private catastrophe insurance. See http://xw.sinoins.com/2014-07/10/content_120490.htm.

Similar catastrophe insurance arrangement is in Ningbo City. See http://insurance.hexun.com/2014-11-04/170012090.html. 
insurance has also been blunted by expectations of a government bailout. For these reasons, if the laissez-faire theory were followed, the catastrophe insurance market would fail to develop soon in China and also fail to play its potential role in mitigating and financing catastrophe losses.

\section{Public-interest theory}

The public-interest theory of government policy contests laissez-faire theory. It holds that government intervention should correct market failures (such as externalities, imperfect competition, moral hazard, and adverse selection). By solving the suboptimal allocation of resources, government intervention can improve social welfare. ${ }^{169}$ According to this theoretical framework, government intervention is often seen as a substitute for or complement to imperfect coordination in the private markets. ${ }^{170}$ Advocates consider government to have better information and judgment than private insurers and to be able to guide markets wisely. ${ }^{171}$ For developing countries where market failure is more pervasive, government intervention is more urgently needed. Limitations on insurance market infrastructure, lack of liquid capital markets, information asymmetries, and other imperfections associated with the catastrophe insurance market necessitate a government role in developing a private market, according to supporters of public-interest theory. ${ }^{172}$

Even in the United States, where Americans have long believed in the gospel of free markets, government intervention in the management of private-sector risks is nothing new. ${ }^{173}$ The government and private lenders want savers to feel confident in their banks and credit unions so that the system of saving and lending is maintained. ${ }^{174}$ As a result, the

169 J.D. Cummins and O. Mahul, Catastrophe Risk Financing in Developing Countries: Principles for Public Intervention 84-85 (2009).

170 C.M. Lewis and K.C. Murdock, Alternative Means of Redistributing Catastrophic Risk in a National Risk Management System in The Financing of Catastrophe Risk 74 (K. Froot ed., 1999).

171 Masahiko Aoki, Kevin Murdock and Masahiro Okuno-Fujiwara, Beyond the East Asian Miracle: Introducing the Market-Enhancing View in The Role of Government in East Asian Economic Development: Comparative Institutional Analysis (Masahiko Aoki, Hyung-Ki Kim and Masahiro Okuno-Fujiwara eds., 1998).

172 J.D. Cummins and O. Mahul, Catastrophe Risk Financing in Developing Countries: Principles for Public Intervention 84-85 (2009).

173 David A. Moss, When All Else Fails: Government as the Ultimate Risk Manager 17 (2004).

174 Sophie M. Korczyk, Insuring the Uninsurable: Private Insurance Markets and Government Intervention in Cases of Extreme Risks, NAMIC Issue Analysis (2005). 
deposit insurance system and the Federal Deposit Insurance Corporation were established in order to prevent the type of mass banking panic that crippled the American financial system in the early 1930s and to protect depositors and maintain confidence in the banking system. ${ }^{175}$ The US government and consumers wanted to ensure an adequate level of farming activity even in the face of potentially catastrophic weather risks, so that the nation was not excessively dependent on imported food. ${ }^{176}$ As a result, the Federal Crop Insurance Program, which is administered by the Federal Crop Insurance Corporation within the US Department of Agriculture, was established. ${ }^{177}$ The government and employers wanted people to continue to live and work in certain geographic areas, e.g., the Borough of Manhattan in New York City and Silicon Valley in California, where there are risks, though infrequent, of terrorist attacks, floods, hurricanes, and earthquakes. ${ }^{178}$ As a result, the Terrorism Risk Insurance Act was passed in November 2002, which provided government reinsurance of terrorist risks, and the National Flood Insurance Program was established and sponsored by the government. The California Earthquake Authority is also quasi-public. ${ }^{179}$ When private insurers have failed to emerge or withdrawn underwriting, in consideration of the public interest, the US government has chosen to secure continuing insurance markets.

Although market failure and the need for economies of scale are common justifications for the government to intervene in an insurance market, these are not, alone, sufficient to improve the allocation of resources. ${ }^{180}$ On the contrary, many public insurance programs have been shown to be inefficient. The US National Flood Insurance Program is an example. The federal government is unlikely to implement general insurance underwriting principles, such as risk segregation, price discrimination to control adverse

175 Tom Baker and David Moss, Government as Risk Manager in New Perspectives on Regulation 87 (David Moss and John Cisternino eds., 2009).

176 Veronique Bruggeman, Compensating Catastrophe Victims: A Comparative Law and Economics Approach 193-195(2010).

177 Barry J. Barnett, US Government Natural Disaster Assistance: Historical Analysis and a Proposal for the Future, 23 Disasters 139 (1999).

178 Sophie M. Korczyk, Insuring the Uninsurable: Private Insurance Markets and Government Intervention in Cases of Extreme Risks, NAMIC Issue Analysis (2005).

179 Dwight Jaffee and Thomas Russell, The Welfare Economics of Catastrophe Losses and Insurance, 38 The Geneva Papers on Risk and Insurance-Issues and Practice 469 (2013).

180 Sophie M. Korczyk, Insuring the Uninsurable: Private Insurance Markets and Government Intervention in Cases of Extreme Risks, NAMIC Issue Analysis (2005). 
selection, and mechanisms to control moral hazard, because of political pressure and lack of market experience. ${ }^{181}$ As a result, the non-risk-based premiums tend to distort the market price and encourage policyholders to overinvest in risky areas and to take inadequate steps to mitigate losses.

In contrast with laissez-faire theory, public-interest theory requires government to act as a substitute for coordination in the private markets. However, public-interest theory is not suitable for China's market-oriented transition and reform. At present, China is still struggling through the transition from a centrally planned economy to a market economy. No independent business sectors or free markets existed until 1978. ${ }^{182}$ During the transition process, China adopted a gradual dual-track approach, rather than shock therapy, and moved slowly to a well-functioning market economy. ${ }^{183}$ The experience of the dual-track approach shows that the more energetic power is coming from private companies. They, as opposed to state-owned enterprises, played a significant role in economic growth. The existence of state-owned enterprises is mainly due to political consideration, to avoid the collapse of old-priority industries, and to maintain rents for those who may be negatively affected by the shift towards a market system. ${ }^{184}$ Nonetheless, the dual-track approach as the transitional arrangement can hardly serve as the permanent foundation for further development, and China needs to move from the dual tracks of planned economy and market economy to a single-track market economy. ${ }^{185}$

If China adopted public-interest theory, the threat of a reunion of the government and the state-owned insurance enterprises would become reality and we would see the dual-track approach backslide to the single-track planned economy. ${ }^{186}$ The case of a collaborative rural house insurance

181 Adam F. Scales, A Nation of Policyholders: Governmental and Market Failure in Flood Insurance, 26 Mississippi College Law Review 3 (2006).

182 Feng Wang and Haitao Yin, A New Form of Governance or the Reunion of the Government and Business Sector? A Case Analysis of the Collaborative Natural Disaster Insurance System in the Zhejiang Province of China, 15 International Public Management Journal 429 (2013).

183 Justin Yifu Lin, Demystifying the Chinese Economy, 46 The Australian Economic Review 259 (2013).

184 Justin Yifu Lin, Demystifying the Chinese Economy, 46 The Australian Economic Review 259 (2013).

185 Justin Yifu Lin, Demystifying the Chinese Economy 178 (2012).

186 Feng Wang and Haitao Yin, A New Form of Governance or the Reunion of the Government and Business Sector? A Case Analysis of the Collaborative Natural Disaster Insurance System in the Zhejiang Province of China, 15 International Public Management Journal 429 (2013). 
system in the Zhejiang Province is a vivid example of such challenges. In this program, initiated in 2006, insurance products are primarily designed by the government and marketed through administrative mobilization instead of market channels run by the People's Insurance Company of China (PICC; Zhejiang branch). Even though the provisions of "The Notice of Developing Rural House Insurance" (2006) require that the operations of the market should follow the principles: (i) insurance companies operate based on market mechanisms and (ii) government promotes insurance coverage through subsidization. ${ }^{187}$ Legislation states clearly that the insurance company, rather than the government, should be the primary operator as an independent market entity. In fact, however, the government intervenes in an all-encompassing manner, and there are no incentives for insurance companies to market products; additionally, since only People's Insurance Company of China Property and Casualty Company Limited ("PICC P\&C") is allowed to participate in such business, this company free rides on government efforts and enjoys monopolistic benefits. ${ }^{188}$ As a result, a well-functioning and effective rural house insurance market is far from being established. ${ }^{189}$

\section{Market-enhancing theory}

The market-enhancing theory of government policy is different from both laissez-faire theory and public-interest theory and takes a middle position. It recognizes that market failure leads to suboptimal allocation of resources and thus suggests that the government can facilitate more efficient coordination in the private sector and enhance the development of the private market. It also suggests that government should not substitute or replace the private sectors and should especially avoid creating permanent new government institutions to substitute for private insurers. ${ }^{190}$ This theory was first applied by Lewis and Murdock to managing catastrophe disaster

187 Zhejiang Provincial Government, The Notice of Developing Rural House Insurance (November, 2006), available at http://www.zjmz.gov.cn/il.htm?a=si\&id $=4028 \mathrm{e} 4812 \mathrm{c} 33 \mathrm{ef} 74012 \mathrm{c} 9 \mathrm{c} 000 \mathrm{~b} 4 \mathrm{e} 0582$.

188 Feng Wang and Haitao Yin, A New Form of Governance or the Reunion of the Government and Business Sector? A Case Analysis of the Collaborative Natural Disaster Insurance System in the Zhejiang Province of China, 15 International Public Management Journal 429 (2013).

189 Feng Wang and Haitao Yin, A New Form of Governance or the Reunion of the Government and Business Sector? A Case Analysis of the Collaborative Natural Disaster Insurance System in the Zhejiang Province of China, 15 International Public Management Journal 429 (2013).

190 J.D. Cummins and O. Mahul, Catastrophe Risk Financing in Developing Countries: Principles for Public Intervention 84-85 (2009). 
risk as early as the 1990s. ${ }^{191}$ It has been widely discussed by scholars and international financial institutions, such as the World Bank. ${ }^{192}$

Market-enhancing theory represents a new kind of government intervention that helps facilitate the creation of private markets and assists private insurers to solve market failures. In contrast to laissez-faire theory, this framework looks for the role of government in achieving more efficient market equilibrium. This is particularly true for transitional and developing countries where private institutions are more limited and presently unable to solve all market failures. ${ }^{193}$ In contrast to publicinterest theory - the traditional government intervention - it promotes the decentralized decision making of private insurers and avoids creating bureaucracy. In other words, the provision of catastrophe insurance policies should be left to private insurers. ${ }^{194}$ This is particularly important for transitional countries where, under the impact of a planned economy, government is still powerful and might be tempted to meddle in micromanagement of insurance activities. As is well known, the establishment of efficient catastrophe insurance programs depends on the integration of four key components: risk assessment, risk pooling, risk segregation, and

191 See C.M. Lewis and K.C. Murdock, The Role of Government Contracts in Discretionary Reinsurance Markets for Natural Disasters, 63 Journal of Risk and Insurance 567 (1996); C.M. Lewis and K.C. Murdock, Alternative Means of Redistributing Catastrophic Risk in a National Risk Management System in The Financing of Catastrophe Risk 51 (K. Froot, ed., 1999).

192 See, e.g. Eugene Gurenko, Rodney Lester, Olivier Mahul and Serap Oguz Gonulal, Earthquake Insurance in Turkey: History of the Turkish Catastrophe Insurance Pool (2006); Thomas Hellmann, Kevin Murdock and Joseph Stiglitz, Financial Restraint and the Market Enhancing View in IEA Conference Volume Series 2559 (1998); J.D. Cummins and O. Mahul, Catastrophe Risk Financing in Developing Countries: Principles for Public Intervention 84-85 (2009); Veronique Bruggeman, Compensating Catastrophe Victims: A Comparative Law and Economics Approach 193-195 (2010); World Bank, Country Insurance: Reducing Systemic Vulnerabilities in Latin America and the Caribbean, Report 43066-LAC (2007); World Bank, India: National Agricultural Insurance Scheme: Market-Based Solutions for Better Risk Sharing, Report 39353 (2007); World Bank, The World Bank Group's Catastrophe Risk Financing Products and Services, World Bank Catastrophe Risk Insurance Working Group (2008).

193 Masahiko Aoki, Kevin Murdock and Masahiro Okuno-Fujiwara, Beyond the East Asian Miracle: Introducing the Market-Enhancing View in The Role of Government in East Asian Economic Development: Comparative Institutional Analysis (Masahiko Aoki, Hyung-Ki Kim and Masahiro Okuno-Fujiwara eds., 1998).

194 C.M. Lewis and K.C. Murdock, Alternative Means of Redistributing Catastrophic Risk in a National Risk Management System in The Financing of Catastrophe Risk 74 (K. Froot ed.,1999). 
control of moral hazard. ${ }^{195}$ The government should create a legal environment to enhance the private development of these components rather than get involved in the details of setting premiums and underwriting policies.

This theoretical framework has many merits. It helps establish an effective and sustainable catastrophe risk financing system with collaboration between government and private insurers. The government avoids acting as a direct insurer, but it can act as a reinsurer or lender of last resort when private underwritings are unavailable or inadequate. ${ }^{196}$ More importantly, this theoretical framework encourages public-private partnership, which could help facilitate access to international reinsurance and capital markets to generate affordable products for domestic insurers. ${ }^{197}$ In practice, this market-enhancing theoretical framework has already attracted the attention of international financial institutions like the World Bank, which guides government intervention in catastrophe risk markets of low- and middle-income countries. ${ }^{198}$ In 2000, the Turkish Catastrophe Insurance Pool (TCIP) was established with the assistance of the World Bank in the aftermath of the Marmara Earthquake. ${ }^{199}$ The TCIP is managed by a board of seven members; insurance companies cede 100 percent of all risk to the pool; the adjustment of claims is done by independent loss adjustors; and the full risk capital requirements of the TCIP are funded through commercial reinsurance, including Milli Re and Munich Re. ${ }^{200}$ The TCIP sold more than 4.8 million policies set at market-based premium rates in 2012, compared to 600,000 covered households when the pool was set up, and penetration rate rose to 29 percent nationwide. ${ }^{201}$ A similar catastrophe pool is being developed in Romania, and there are

195 J.D. Cummins and O. Mahul, Catastrophe Risk Financing in Developing Countries: Principles for Public Intervention 87 (2009).

196 J.D. Cummins and O. Mahul, Catastrophe Risk Financing in Developing Countries: Principles for Public Intervention 87 (2009).

197 J.D. Cummins and O. Mahul, Catastrophe Risk Financing in Developing Countries: Principles for Public Intervention 87 (2009).

198 J.D Cummins and O. Mahul, Catastrophe Risk Financing in Developing Countries: Principles for Public Intervention 8-9 (2009).

199 Johann-Adrian von Lucius, A Reinsurance Perspective on the Turkish Catastrophe Insurance Pool in Catastrophe Risk and Reinsurance: A Country Risk Management Perspective 217 (Euguene N. Gurenko ed., 2004).

200 Johann-Adrian von Lucius, A Reinsurance Perspective on the Turkish Catastrophe Insurance Pool in Catastrophe Risk and Reinsurance: A Country Risk Management Perspective 217 (Euguene N. Gurenko ed., 2004).

201 Turkish Catastrophe Insurance Pool (TCIP) English Annual Reports (2012), available at http://www.tcip.gov.tr/content/annualReport/2012_Annual_ Report_DASK.pdf. 
now even multiple-country regional organizations, such as the Caribbean Catastrophe Risk Insurance Facility. ${ }^{202}$

In addition, market-enhancing theory consists of government regulation of private insurance. Think of all of the regulatory techniques that apply to private insurers in the United States, European Union and other countries, including entry controls, minimum capital requirements, other types of solvency regulation, regulation of forms, and prohibitions against unfair trade practices. If a private catastrophe insurance market takes off in China, some or all of those types of regulation in the interest of solvency and consumer protection are warmly welcomed (and the CIRC already does that for other types of insurance in China).

Like many other areas of the economy, the developing catastrophe insurance market in China can draw lessons from the accumulated achievements of the ongoing socioeconomic reforms - the so-called Chinese miracle. ${ }^{203}$ The essence of China's "miracle" is consistent with market-enhancing theory, rather than laissez-faire theory or publicinterest theory. ${ }^{204}$ The Chinese approach stresses the fundamental role of the market in resource allocation but also expects the government to play a facilitating role by addressing externalities, coordination, and many other market-failure issues. ${ }^{205}$

202 J.D. Cummins and O. Mahul, Catastrophe Risk Financing in Developing Countries: Principles for Public Intervention 93 (2009).

203 Elizabeth J. Perry, Growing Pains: Challenges for a Rising China, 143 Daedalus 5 (2014).

204 Simply speaking, the main experiences of China's "miracle" development are: (i) well-functioning competitive markets, which are the precondition for developing a country's industries because only with such a market can prices reflect scarcities of production in the economy and propel firms to enter industries; (ii) a proactive, facilitating government, which is equally important because, for transitional countries, the government should seize and capture the advantages of late-comers through playing a role in information collection, coordination, and compensation for externalities. See Justin Yifu Lin, Demystifying the Chinese Economy, 46 The Australian Economic Review 259 (2013).

205 The Chinese approach strives to institute a new hybrid system, which, indeed, is the market-enhancing approach. China does not follow shock therapya policy recommendation based on orthodox economic theory-promoting economic liberalization and privatization, which is more or less the application of laissez-faire theory. The failure of Russian's transition, a typical example of shock therapy, however, reveals that the liberalization-cum-privatization approach does not automatically bring about efficient and sustainable market structures. China's success and Russia's failure prove that in developed countries the government should perhaps interfere less, but for transitional countries, a minimalist government is not optimal. On the other hand, a strong, proactive and facilitating state could start and enhance genuine market-oriented reforms, because the leaders of 
Considering the low-probability but high-consequence nature of catastrophe risk and the currently immature condition of the insurance market and economic development, the market-enhancing theory could be the proper guiding theory to develop a catastrophe insurance market in China. In addition, market-enhancing theory conforms to the practice of catastrophe insurance pilot programs in China. The market-enhancing theory emphasizes the importance of local information and suggests that decentralized private agents can use locally available information to come up with market-based solutions that are significantly more efficient than those that could be imposed by a central authority. ${ }^{206}$

Nonetheless, potential challenges should be closely examined when applying the market-enhancing theory in China. China has not transitioned into a market economy despite decades of reform. Thus, government may easily slide into intervening in microbusiness activities in the name of public interest, due to path dependency. ${ }^{207}$ The case of the collaborative rural house insurance system, which mainly covers the losses caused by natural disasters in the Zhejiang Province of China, is a reflection of how

China recognize that only genuine market reforms and sustained economic growth that benefits all strata of society — not just the political elite and big business - can supply their political legitimacy. This direction differs from the public-interest theory, which requires government to act as a substitute for private sectors. See Justin Yifu Lin, New Structural Economics: A Framework for Rethinking Development, 26 The World Bank Research Observer 193 (2011). Justin Yifu Lin, the former Chief Economist and Senior Vice President of the World Bank (2008-2012), based on China's experiences of development, raised new structure theory as a theoretical explanation. See Justin Yifu Lin, Demystifying the Chinese Economy (2012); Justin Yifu Lin, New Structural Economics: A Framework for Rethinking Development (2012); Justin Yifu Lin, The Quest for Prosperity: How Developing Economies Can Take Off (2012). See also J. Ahrens, Governance in the Process of Economic Transformation in System Transformation in Comparative Perspective: Affinity and Diversity in Institutional, Structural and Cultural Patterns (M. Jovanovic, L. Dalgon, O. Yeon-Chean S. Park and B. Seliger eds., 2007).

206 C.M. Lewis and K.C. Murdock, Alternative Means of Redistributing Catastrophic Risk in a National Risk Management System in The Financing of Catastrophe Risk 77 (K. Froot ed., 1999).

207 V. Nee and Y. Cao, Path Dependent Societal Transformation: Stratification in Hybrid Mixed Economies, 28 Theory and Society 799 (1999): "The theory of path dependence states that history matters for contemporary institutional development." See S.J. Liebowitz and S.E. Margolis, Path Dependence, 1 Encyclopedia of Law and Economics 981 (2000): "Based on state-centered accounts of transitions, the long-standing vertical ties linking government bureaus with economic actors perpetuate patterns of government and business relationships deeply entrenched in economy and society." 
the government and the insurance companies work with each other in a way similar to how they would operate in a planned economy. ${ }^{208}$

\section{A short conclusion}

By examining laissez-faire theory, public-interest theory, and marketenhancing theory, I suggest that market-enhancing theory might be a proper theoretical guide for the development of a catastrophe insurance market in China. As Ronald Coase said, "satisfactory views on policy can only come from a patient study of how, in practice, the market, firms, and governments handle the problem of harmful effects". ${ }^{209}$ Such study indicates that devising a private catastrophe insurance market system and enhancing the role of insurance in addressing catastrophe losses has become an urgent challenge in China.

\section{Principles for Government Intervention in the Catastrophe Insurance Market}

Based on the above analysis of market-enhancing theory and the experiences of China's transitional development, I propose a catastrophe insurance market-enhancing framework to coordinate the role of government and market in catastrophe risk management in China. The content of this framework has three pillars:

- Sustaining a strong and capable government

- Enhancing the market, while neither supplanting nor retarding it

- Legalizing the relationship between government and market to prevent government from undermining well-functioning market operations

To efficiently apply the catastrophe insurance market-enhancing framework, and to help establish a well-functioning catastrophe insurance market and disaster compensation system, ${ }^{210} \mathrm{I}$ further propose three

208 Feng Wang and Haitao Yin, A New Form of Governance or the Reunion of the Government and Business Sector? A Case Analysis of the Collaborative Natural Disaster Insurance System in the Zhejiang Province of China, 15 International Public Management Journal 429 (2013).

209 Ronald Coase, The Problem of Social Cost, 3 Journal of Law and Economics 1 (1960).

210 Based on the comparative analysis of types of systems in different countries, the ideal standard consists of: (i) financially sustainable, (ii) adequate policies for preventing and mitigating risks, and (iii) the provision of affordable insurance 
principles to facilitate government intervention in the catastrophe insurance market:

- Principle 1. Government should help solve market failures in catastrophe insurance and secure insurers' business operations using market mechanisms, rather than creating new government institutions to supplant private solutions.

- Principle 2. Government may establish a mandatory catastrophe insurance system through legislation and help solve the affordability problem at the same time.

- Principle 3. Government should reform the Whole-Nation System to avoid crowding out private insurance and enhance the collaboration between the insurance industry and the government.

\section{Government responsibilities under Principle 1}

Due to insurability limits with catastrophe risk and the high potential losses of catastrophe exposures, insurers lack the capacity and appetite to sufficiently cover all such losses.

(a) The predictability condition of insurability Insurability of catastrophe risk is an important consideration for insurers when they decide whether to underwrite policies. If the risk is not insurable, insurers will have no appetite, even if they have financial capacity to write more business. Generally speaking, there are two agreed-upon requirements for insurability: (i) the insurer must have the ability to identify, quantify, and estimate the chances of disasters and the resulting losses; (ii) the insurer must have the ability to set and collect appropriate premiums for catastrophe risks. ${ }^{211}$ To help fulfill the insurability requirements, governments can assist insurers with risk assessment, mapping risk zones, information flows, and so on.

Risk assessment is used to discover the underlying actuarial costs

with low management expenses to a broad public in hazard-prone areas. See J.R. Skees and B.J. Barnett, Conceptual and Practical Considerations for Sharing Catastrophic/Systemic Risks, 21 Review of Agricultural Economics 424 (1999); Youbaraj Paudel, A Comparative Study of Public-Private Catastrophe Insurance Systems: Lessons from Current Practices, 37 The Geneva Papers on Risk and Insurance-Issues and Practice 257 (2012).

211 Howard Kunreuther and E.O. Michel-Kerjan, Climate Change, Insurability of Large-Scale Disasters, and the Emerging Liability Challenge, 155 University of Pennsylvania Law Review 1795 (2007); Howard Kunreuther and R.J. Roth, Sr, Paying the Price: the Status and Role of Insurance against Natural Disasters in the United States 27-38 (1998). 
of catastrophe risk and help set accurate risk-adjusted premiums. ${ }^{212} \mathrm{It}$ requires data collection, catastrophe risk modeling, and other technical support. Government, for example, has the advantage in data collection of natural disasters due to its disaster-relief experiences. Mapping risk zones can be regarded as a means of risk assessment because it depicts and summarizes specific hazard risks of properties or zones. ${ }^{213}$ It could best be conducted through collaboration between governments and insurers. ${ }^{214}$ For example, European countries were required to prepare flood hazard and flood risk maps before 2014 to comply with the 2007 European Flood Risk Management Directive. ${ }^{215}$ Insurance businesses are heavily dependent on information flows, which include information flowing from policyholder to intermediaries, from intermediaries to insurers, and from insurers to reinsurers. ${ }^{216}$ If information cannot flow smoothly and accurately, it will not only increase transaction costs but make it difficult for insurers/reinsurers to identify, quantify, and correctly estimate the chances of disasters occurring and the resulting losses.

(b) Increasing the capacity of the insurance industry Due to the highly correlated and aggregate nature of natural disasters, the potential losses from catastrophe risks are large and uncertain. At this stage, China's insurers may still lack sufficient financial capacity to fully cover catastrophe losses. The total net capital of China's property insurance companies is much lower than the total amount of losses caused by natural disasters.

As early as 1992, following Hurricane Andrew, US insurers realized that outside capital was needed to supplement the industry's capacity. ${ }^{217}$ The government can enhance the use of capital markets as a financing

212 J.D. Cummins and O. Mahul, Catastrophe Risk Financing in Developing Countries: Principles for Public Intervention 76-77 (2009).

213 Youbaraj Paudel, A Comparative Study of Public-Private Catastrophe Insurance Systems: Lessons from Current Practices, 37 The Geneva Papers on Risk and Insurance-Issues and Practice 257-285 (2012).

214 Youbaraj Paudel, A Comparative Study of Public-Private Catastrophe Insurance Systems: Lessons from Current Practices, 37 The Geneva Papers on Risk and Insurance-Issues and Practice 257 (2012).

215 J. Van Alphen, F. Martini, R. Loat, R. Slomp and R. Passchier, Flood Risk Mapping in Europe, Experiences and Best Practices, 2 Journal of Flood Risk Management 285 (2009).

216 J.D. Cummins and O. Mahul, Catastrophe Risk Financing in Developing Countries: Principles for Public Intervention 31-32 (2009).

217 R. King, Hurricanes and Disaster Risk Financing Through Insurance: Challenges and Policy Options, Congressional Research Service, R132825 (2005). 
Table 1.6 Capital of main Chinese property insurers compared to natural disaster losses (US\$ billions)

\begin{tabular}{lrrrr}
\hline & 2007 & 2008 & 2009 & 2010 \\
\hline Net capital of main insurers & 5.5 & 5.1 & 6.9 & 9.0 \\
Natural disaster losses & 38.1 & 189.5 & 40.1 & 86.1 \\
\hline
\end{tabular}

Source: Yearbook of China Insurance (2008-2011).

mechanism for insurance through equity stakes by outside investors in insurance companies, bond issuances, securitization, etc. This is particularly important for the Chinese government because its insurance/ reinsurance market and capital markets are still in their infancy. To make the enhancement of capital markets work, the government should facilitate its development by eliminating market barriers, reducing transaction costs, and ensuring the rule of law for those markets.

In addition, government may act as a reinsurer to help increase the capacity of the insurance industry. Effective and sustainable catastrophe risk financing solutions require collaboration between government and private insurers, especially in the case of extreme catastrophes when the private reinsurance market "hardens". ${ }^{218}$ The designers of the government's role as reinsurer may learn from the well-functioning Turkish Catastrophe Insurance Pool (TCIP). When earthquake losses in Turkey exceed $\$ 80$ million, the excess losses are transferred to the reinsurance market. ${ }^{219}$ The Turkish government covers "losses that would exceed the overall claims paying capacity of the TCIP, which is currently sufficient to withstand a 1-in-350 year earthquake". ${ }^{220}$ The TCIP is supported by the

218 For example, in France and Japan, where catastrophe coverage is mandatory, all catastrophe insurance policies written by private insurers are reinsured by the government-run reinsurance company, which essentially serves as guarantor for all policies written. In the US, under the Terrorism Risk Insurance Act of November 2002, the federal government agreed to provide a kind of reinsurance "backstop" for terrorism losses. See Milton Nektarios, A Catastrophe Insurance System for the European Union, 5 Asia-Pacific Journal of Risk and Insurance, Article 6 (2011); Thomas Russell and Jeffrey E. Thomas, Government Support for Terrorism Insurance, 15 Connecticut Insurance Law Journal 183 (2008).

219 Johann-Adrian von Lucius, A Reinsurance Perspective on the Turkish Catastrophe Insurance Pool in Catastrophe Risk and Reinsurance: A Country Risk Management Perspective 217 (Eugene N. Gurenko ed., 2004).

220 Turkish Catastrophe Insurance Pool, available at http://www.gfdrr.org/ sites/gfdrr.org/files/documents/DFI_TCIP_Jan11.pdf. 
World Bank, which provides financial and technical assistance. ${ }^{221}$ As the first national catastrophe insurance pool in World Bank-client countries, the TCIP is a good model for China.

Besides acting as a reinsurer of last resort to increase the capacity of the insurance industry, the government could sell industry-level, excess-of-loss contracts for insured disaster losses as a last resort, as proposed by Lewis and Murdock. ${ }^{222}$

(c) Promoting risk classification and encouraging risk-based premiums Risk classification and risk-based premiums are the heart of a healthy insurance business. ${ }^{223}$ Only by segregating policyholders into different risk pools can insurers charge different premiums for different pools, reduce adverse selection, and incentivize risk reduction by policyholders, and thus make profits. ${ }^{224}$ However, government and government-run catastrophe insurance systems are unlikely to implement this basic principle when faced with political pressures 225 because risk classification is not always compatible with social solidarity objectives that promote equal treatment of all citizens. ${ }^{226}$ Therefore, the government should neither create new institutions to supplant private solutions nor depress premiums on insurance policies. Instead, it should allow insurers to set the premiums to reflect risks. Even if there are concerns about the affordability of

221 Turkish Catastrophe Insurance Pool, available at http://www.gfdrr.org/ sites/gfdrr.org/files/documents/DFI_TCIP_Jan11.pdf.

222 Excess-of-loss contracts are "designed to complement existing privatesector insurance and reinsurance mechanisms by covering only layers of reinsurance currently unavailable in the private market ... These contracts, which are equivalent to call-spread options written on an industry index of disaster losses, would be auctioned to qualified insurance companies and would carry a maturity of one year". See C.M. Lewis and K.C. Murdock, Alternative Means of Redistributing Catastrophic Risk in a National Risk Management System in The Financing of Catastrophe Risk 80 (K. Froot ed., 1999).

223 Kenneth S. Abraham, Efficiency and Fairness in Insurance Risk Classification, 71 Virginia Law Review 403 (1985).

224 Ronen Avraham, Kyle D. Logue and Daniel Schwarcz, Understanding Insurance Antidiscrimination Laws, 87 Southern California Law Review 195 (2014).

${ }_{225}$ Youbaraj Paudel, A Comparative Study of Public-Private Catastrophe Insurance Systems: Lessons from Current Practices, 37 The Geneva Papers on Risk and Insurance-Issues and Practice 257 (2012) ("In general, the fully public private insurance systems have not integrated risk-based premiums and financial incentives for mitigation").

226 J.D. Cummins and O. Mahul, Catastrophe Risk Financing in Developing Countries: Principles for Public Intervention 76-78 (2009). 
catastrophe insurance, it is better to take measures from the perspective of consumer demand (such as insurance vouchers, discussed below) than to depress insurers' incentives to underwrite policies and distort risk signals provided by actuarially based premiums. As a Chinese proverb has it, "you can't expect the horse to run fast when you don't let it graze". Government cannot expect insurers to underwrite policyholders' risks if it does not let them make profits.

(d) Encouraging disaster mitigation activities Disaster mitigation activities can benefit both policyholders and insurers because they decrease the costs of the catastrophe insurance system in the long run. Catastrophe insurance systems in different countries encourage mitigation activities. ${ }^{227}$ The government should encourage disaster mitigation policies that include but are not limited to conducting natural disaster risk investigation and zoning; establishing natural disaster monitoring systems and earlywarning systems; implementing building code standards; pushing forward natural disaster prevention projects; and investing in public protection infrastructure. ${ }^{228}$

\section{Government responsibilities under Principle 2}

Due to the low-probability but high-consequence nature of catastrophe risk, supply of and demand for catastrophe insurance is low. Principle 2 attempts to solve this issue by establishing a mandatory system.

(a) Establishing a mandatory catastrophe insurance system Probably one of the most debated issues in establishing catastrophe insurance systems is whether those systems should be mandatory. Unlike private insurers, the government or lawmakers have power to compel consumers to participate in insurance programs, no matter whether those programs are governmentrun or private-run insurance. ${ }^{229}$ Opponents and proponents both advance

227 Youbaraj Paudel, A Comparative Study of Public-Private Catastrophe Insurance Systems: Lessons from Current Practices, 37 The Geneva Papers on Risk and Insurance-Issues and Practice 257 (2012).

228 Office of National Commission for Disaster Reduction, P.R. China, China's Natural Disaster Risk Management in Improving the Assessment of Disaster Risks to Strengthen Financial Resilience 121 (A Special Joint G20 Publication by the Government of Mexico and the World Bank, 2012); Youbaraj Paudel, A Comparative Study of Public-Private Catastrophe Insurance Systems: Lessons from Current Practices, 37 The Geneva Papers on Risk and InsuranceIssues and Practice 257 (2012).

229 David A. Moss, When All Else Fails: Government as the Ultimate Risk Manager 49-50 (2004). 
arguments to justify their positions. ${ }^{230}$ Generally speaking, the potential challenges associated with the mandatory catastrophe insurance system include (i) violating freedom of contract, (ii) cross-subsidization, and (iii) anticompetition. In contrast, the potential benefits generally include (i) correcting irrational behaviors to justify infringements on freedom of contract, (ii) managing adverse selection to justify cross-subsidization, (iii) enhancing national solidarity to justify anticompetition, and (iv) promoting damage mitigation. Although there are several (potential) challenges to a mandatory insurance system, the advantages often justify this system.

More importantly, due to the low-probability nature of catastrophe risks and the reliance on government bailouts under the Whole-Nation System, Chinese consumers have little incentive to purchase catastrophe insurance products voluntarily. Like consumers everywhere, Chinese citizens do not always behave rationally and maximize their expected utility to protect themselves from catastrophe losses by buying insurance. Prior to a disaster, consumers believe that natural disasters will not happen to them. ${ }^{231}$

230 An overview of the debate is as follows: Kunreuther proposed a mandatory model as early as 1968 . This opinion was repeated by other scholars, especially after Hurricane Katrina, and also received support from European scholars. See Howard Kunreuther, The Case for Comprehensive Disaster Insurance, 11 Journal of Law and Economics 133 (1968); Howard Kunreuther, Has the Time Come for Comprehensive Natural Disaster Insurance? in On Risk and Disaster: Lessons from Hurricane Katrina 175, 175 (Ronald Daniels, Donald F. Kettl and Howard Kunreuther eds., 2006); Howard Kunreuther and Mark Pauly, Rules rather than Discretion: Lessons from Hurricane Katrina, 33 Journal of Risk \& Uncertainty 101, 102-104 (2006); Anastasia Telesetsky, Insurance as a Mitigation Mechanism: Managing International Greenhouse Gas Emissions through Nationwide Mandatory Climate Change Catastrophe Insurance, 27 Pace Environmental Law Review 691 (2010). European scholarship includes: Reimund Schwarze and Gert G. Wagner, In the Aftermath of Dresden: New Directions in German Flood Insurance, 29 The Geneva Papers on Risk and Insurance-Issues and Practice 154, 163 (2004); Michael G. Faure, Insurability of Damage Caused by Climate Change: A Commentary, 155 University of Pennsylvania Law Review 1875 (2007); Michael Faure and Veronique Bruggeman, Catastrophic Risks and First-Party Insurance, 15 Connecticut Insurance Law Journal 1 (2008). On the other hand, some literature indicates the potential dangers to mandatory insurance system, such as regulatory paternalism, anticompetition, and overgeneralization. See Anthony I. Ogus, Regulatory Paternalism: When Is It Justified? in Corporate Governance in Context: Corporations, States, and Markets in Europe, Japan and the US 303, 303 (Klaus J. Hopt et al. eds., 2005); Scott E. Harrington, Rethinking Disaster Policy, 23 Regulation 40 (2000).

231 Shlomo Benartzi and Richard Thaleer, Myopic Loss Aversion and the Equity Premium Puzzle, 110 Quarterly Journal of Economics 73 (1995). 
(b) Solving the affordability problem When deciding to establish a mandatory catastrophe insurance system, there is an obvious tension between a high-risk-based premium and affordability, given the severity and spatial correlation of catastrophe losses. ${ }^{232}$ The pricing debate over the National Flood Insurance Program in the United States is a vivid example of this tension. On March 21, 2014, President Obama signed the Homeowner Flood Insurance Affordability Act of 2014, which responded to political complaints of "unaffordability" by repealing and softening certain provisions of the Biggert-Waters Flood Insurance Reform Act of 2012, which moved toward premiums reflecting risk. ${ }^{233}$ The affordability problem is even more severe in China as a developing country.

A government may provide basic coverage for residents. The basic coverage of catastrophe losses as part of social safety net programs could be justified because the public social insurance is insufficient in China. ${ }^{234}$ However, this coverage should be implemented via ex ante catastrophe insurance rather than compensating victims directly via the ex post Whole-Nation System, which faces many problems. From this perspective, outsourcing coverage via purchasing insurance may be more efficient.

Ideally, coverage of catastrophe losses can be regarded as an integrated system consisting of different layers. Government coverage is just the first layer, and the remaining layers supplied by private insurers can cover broader exposures. In this instance, to solve the affordability problem of poor people, the government could supply insurance vouchers rather than traditional direct-premium subsidies to insurance buyers. One example of a direct-premium subsidy is an arrangement where 50 percent of the risk-based premium is paid by policyholders and the rest is paid by the government. ${ }^{235}$ Direct-premium subsidies that depress premiums "tend to have highly distortional implications for the insurance markets and risk management behavior of the policyholders". ${ }^{236}$ The US Crop Insurance Program and India's National Agricultural Insurance Scheme are two

232 Carolyn Kousky and Howard Kunreuther, Addressing Affordability in the National Flood Insurance Program, 01 Journal of Extreme Events 1450001 (2014).

233 FEMA, Homeowner Flood Insurance Affordability Act: Overview (2014), available at http://www.fema.gov/media-library-data/13965519355974048b68f6d695a6eb6e6e7118d3ce464/HFIAA_Overview_FINAL_03282014.pdf.

234 J.D. Cummins and O. Mahul, Catastrophe Risk Financing in Developing Countries: Principles for Public Intervention 81-83 (2009).

235 J.D. Cummins and O. Mahul, Catastrophe Risk Financing in Developing Countries: Principles for Public Intervention 82-83 (2009).

236 J.D. Cummins and O. Mahul, Catastrophe Risk Financing in Developing Countries: Principles for Public Intervention 82-83 (2009). 
examples demonstrating the imperfection of direct-premium subsidy ${ }^{237}$ The problems of direct-premium subsidies include criticisms that (i) they are untargeted and available to all policyholders, without distinction between low-income households and high-income households; (ii) they tend to become permanent, even though the government initially introduces them as temporary subsidies; (iii) they put an increasing fiscal burden on the government as the scope of the subsidy creeps up; and (iv) they mainly benefit policyholders located in high-risk zones. ${ }^{238}$

In contrast, insurance vouchers that recipients can use like cash but only to buy qualifying insurance could help secure risk-based premiums, ensure that insurers play their correct role, and solve the affordability problem for low-income households. ${ }^{239}$ Unlike a direct-premium subsidy, meanstested insurance vouchers ensure that recipients use the funds for obtaining insurance, without distorting the insurance premium reflecting risk. ${ }^{240}$ The amount of the voucher can be determined by using a sliding scale based on annual family income, and a voucher program could be coupled with mitigation requirements so as to reduce future disaster losses. ${ }^{241} \mathrm{In}$ the United States, there are several kinds of well-functioning voucher programs, such as the Housing Choice Voucher Program, the Food Stamp Program, the Low Income Home Energy Assistance Program, and the Universal Service Fund. ${ }^{242}$

237 J.D. Cummins and O. Mahul, Catastrophe Risk Financing in Developing Countries: Principles for Public Intervention 82-83 (2009).

238 J.D. Cummins and O. Mahul, Catastrophe Risk Financing in Developing Countries: Principles for Public Intervention 82-83 (2009).

239 Carolyn Kousky and Howard Kunreuther, Addressing Affordability in the National Flood Insurance Program, 01 Journal of Extreme Events 1450001 (2014); Howard Kunreuther and Erwann, Michel-Kerjan, Enhancing Post-Disaster Economic Recovery: How Improved Flood Insurance Mechanisms Can Help in Current Research Project Synopses 71 (2014); Erwann Michel-Kerjan, Jeffrey Czajkowski and Howard Kunreuther, Could Flood Insurance be Privatized in the United States? A Primer, 39 The Geneva Papers on Risk and Insurance-Issues and Practice 651 (2015); Howard Kunreuther, Reducing Losses from Catastrophic Risks through Long-Term Insurance and Mitigation, 75 Social Research: An International Quarterly 905 (2008).

240 Howard Kunreuther, Reducing Losses from Catastrophic Risks through Long-Term Insurance and Mitigation, 75 Social Research: An International Quarterly 905 (2008).

241 Carolyn Kousky and Howard Kunreuther, Addressing Affordability in the

National Flood Insurance Program, 01 Journal of Extreme Events 1450001 (2014).

242 Carolyn Kousky and Howard Kunreuther, Addressing Affordability in the National Flood Insurance Program, 01 Journal of Extreme Events 1450001 (2014). 


\section{Government responsibilities under Principle 3}

Principle 3 reflects the need to reform the current catastrophe disaster compensation arrangements under the Whole-Nation System to enhance the collaboration between the insurance industry and the government. Therefore, some arrangements of the Whole-Nation System should be reformed-such as counterpart aid-to avoid crowding out private insurance.

How to coordinate the Whole-Nation System and market-based catastrophe insurance depends on whether relief under the Whole-Nation System crowds out private insurance transactions. Basic rational choice theory tells us that if individuals treat ad hoc relief from the Whole-Nation System as a substitute for insurance, they will underinsure or fail to insure at all. ${ }^{243}$ According to the empirical studies on different post-disaster relief schemes comparing Austria, where governmental relief is certain but incomplete, and Germany, where governmental relief is uncertain but more complete, the results show that "expected governmental relief has a strong crowding-out effect on insurance demand and this effect is even more pronounced when governmental relief is more certain". ${ }^{244}$ In other words, the government relief scheme of Austria has a stronger crowding-out effect for market-based insurance because of its certainty. Unfortunately, China's Whole-Nation System is more like the Austrian than the German model. It means that, under the Whole-Nation System, even introducing market-based catastrophe insurance may not play an expected and desired role. Counterpart aid in the form of direct disaster grants to affected households is an example. This form of assistance is likely to crowd out private insurance markets, according to some researchers.

For example, an empirical study suggests that the direct disaster grants of the US Federal Emergency Management Agency (FEMA) have a

243 Paul A. Raschky, Reimund Schwarze, Manijeh Schwindt and Ferdinand Zahn, Uncertainty of Governmental Relief and the Crowding out of Flood Insurance, 54 Environmental and Resource Economics 179 (2013); Tracy Lewis and David Nickerson, Self-Insurance against Natural Disasters, 16 Journal of Environmental Economics and Management 209 (1989); Louis Kaplow, Incentives and Government Relief for Risk, 4 Journal of Risk and Uncertainty 167 (1991); Mary Kelly and Anne E. Kleffner, Optimal Loss Mitigation and Contract Design, 70 Journal of Risk and Insurance 53 (2003); Carolyn Kousky, Erwann O. Michel-Kerjan and Paul A. Raschky, Does Federal Disaster Assistance Crowd Out Private Demand for Insurance? (August 2014), available at http://opim.wharton.upenn.edu/risk/ library/WP201404_CK-EMK-PAR_Does-assistance-crowd-out-insurance.pdf.

244 Paul A. Raschky, Reimund Schwarze, Manijeh Schwindt and Ferdinand Zahn, Uncertainty of Governmental Relief and the Crowding out of Flood Insurance, 54 Environmental and Resource Economics 179 (2013). 
statistically significant negative impact on average coverage per policy. Kousky et al. state, "A \$1,000 increase in the average IA [Individual Assistance program] grant decreases average insurance coverage by roughly \$6,400". ${ }^{245}$ However, the volume of Small Business Administration disaster loans has no significant effect. ${ }^{246}$ In other words, government loans induce less crowding-out than direct grants. ${ }^{247}$ Counterpart aid under the Whole-Nation System operates much like disaster grants from the IA program and thus would create substantial crowding-out of marketbased insurance. Government loans, however, even at a low interest rate, will induce less crowding-out of insurance than direct disaster grants. Therefore, the form of counterpart aid could be changed into government loans rather than direct disaster grants to reduce this crowding-out effect.

\section{CONCLUSION}

The government is playing an expanding role in catastrophe disaster aid, relief, and compensation all around the world. Government expenditures are sharply rising, not only in the United States and European countries, but elsewhere. ${ }^{248}$ The same is happening in China, where government traditionally plays a fundamental role in dealing with catastrophe disasters.

Based on the above analysis, we may admit that the Whole-Nation System is necessary because it works well in the short run as emergency relief, especially in the absence of a catastrophe insurance market. In addition, the government continues this system because it helps the

245 Carolyn Kousky, Erwann O. Michel-Kerjan and Paul A. Raschky, Does Federal Disaster Assistance Crowd Out Private Demand for Insurance? (August 2014), available at http://opim.wharton.upenn.edu/risk/library/WP201404_CK-E MK-PAR_Does-assistance-crowd-out-insurance.pdf.

246 Carolyn Kousky, Erwann O. Michel-Kerjan and Paul A. Raschky, Does Federal Disaster Assistance Crowd Out Private Demand for Insurance? (August 2014), available at http://opim.wharton.upenn.edu/risk/library/WP201404_CK-EMK-PA R_Does-assistance-crowd-out-insurance.pdf.

247 Carolyn Kousky, Erwann O. Michel-Kerjan and Paul A. Raschky, Does Federal Disaster Assistance Crowd Out Private Demand for Insurance? (August 2014), available at http://opim.wharton.upenn.edu/risk/library/WP201404_ CK-EMK-PAR_Does-assistance-crowd-out-insurance.pdf.

248 J.D. Cummins, M. Suher and G. Zanjani, Federal Financial Exposure to Natural Catastrophe Risk in Measuring and Managing Federal Financial Risk 61 (D. Lucas ed., 2010); European Commission, Disaster Risk Reduction: Increasing Resilience by Reducing Disaster Risk in Humanitarian Action (2013), DG ECHO Thematic Policy Documents, available at http://ec.europa.eu/echo/files/policies/ prevention_preparedness/DRR_thematic_policy_doc.pdf. 
government gain support from the people. ${ }^{249}$ When disaster provides a unique opportunity for the government to show its responsibility and accountability, it is not difficult to imagine that the Whole-Nation System, with its powerful capability, increases people's support for the government. If only for political expediency, it is hard to believe that the Chinese government will give up the Whole-Nation System completely, even if the system has a lot of problems.

Nonetheless, the Whole-Nation System needs reform. It should be combined with private catastrophe insurance to achieve the benefits of both private market and public government. The Whole-Nation System mainly works well in emergency relief. Beyond that, the government should encourage catastrophe insurance, provide risk finance and loss compensation and support insurance in that role.

Alford once raised the question "whether developing countries have a fateful choice: to embrace Western models of professional organization as they now exist, or to set off on an independent path, adapting elements of Western practices to their own historical and cultural situation". ${ }^{250}$ Though the answer may be "blowing in the wind", I wish that the proposed catastrophe insurance market-enhancing framework could help capture some part of that answer. Hopefully, it could shed light on solving the universal dilemma of how to manage catastrophe risk efficiently and cover disaster losses fairly.

249 The impact of natural disasters on support for authorities is conditional on governmental performance during and after the disaster. For a transitional state like China, government's legitimacy depends not only on its economic performance but also on its response and accountability to the people. A similar example presents in Russia. In the summer of 2010 central Russia experienced unprecedented forest fires. The wildfires were the most disastrous in recorded history in Russia. The fires burned more than 500,000 hectares of land, many people died and over 1,200 houses were destroyed. An empirical study conducted in the areas affected by the disaster over the course of the summer of 2011 revealed that rapid government action and generous aid relief led to increased loyalty to the government among those affected by the disaster. See Y.A. Lazarev, A.S. Sobolev, I.V. Soboleva and B. Sokolov, Trial by Fire: A Natural Disaster's Impact on Support for the Authorities in Rural Russia, 66 World Politics 641 (2014).

250 William P. Alford and Kenneth Winston, Introduction in Prospects for the Professions in China 2 (William P. Alford, William Kirby and Kenneth Winston eds., 2011). 